\title{
Organizational Environments in Flux: The Impact of Regulatory Punctuations on Organizational Domains, CEO Succession, and Performance
}

\author{
Heather A. Haveman - Michael V. Russo - Alan D. Meyer \\ Columbia University, Graduate School of Business, 706 Uris Hall, 3022 Broadway, \\ New York, New York 10027-6902 \\ University of Oregon, Lundquist College of Business, Eugene, Oregon 97403-1208 \\ University of Oregon, Lundquist College of Business, Eugene, Oregon 97403-1208 \\ hah15@columbia.edu・mrusso@lcbmail.uoregon.edu・ameyer@lcbmail.uoregon.edu
}

\begin{abstract}
A central debate in organizational theory concerns how organizations evolve. There are two diametrically opposing viewpoints. Adaptation theories predict that change occurs as fluid organizations adjust to meet shifting environmental demands, while selection theories predict that change occurs through the differential selection and replacement of inert organizations as environmental demands vary over time. Our paper bridges these polar opposites by using a punctuated equilibrium framework to examine organizations' responses to discontinuous industrylevel change. This framework recognizes that the histories of many industries are occasionally punctuated by dramatic exogenous shocks, such as radical technological innovation, social and political turmoil, major changes in government regulation, and economic crashes. Our central thesis is that such environmental punctuations dramatically reduce pressures and rewards for organizational inertia and thereby alter both organizations' propensities for change and their survival chances following change.

We focus on one form of punctuation, major regulatory change, and study firms in two industries: general hospitals and savings and loan associations. For organizations in both industries, we examine three important outcomes: shifts in organizational domain, CEO succession, and changes in financial performance. Our analyses show that punctuational regulatory change prompts shifts in organizational domains and executive leadership. Additionally, post-punctuation domain change and post-punctuation CEO succession both affect subsequent performance. We discuss our results in light of current thinking about the content and process effects of core organizational change, which has been developed in the context of stable environments. Finally, we argue for the development of more temporally sensitive theories of organizational action.

(Organizational Evolution; Punctuated Equilibrium; Deregulation; Organizational Change; Organizational Inertia; Organizational Performance; CEO Succession)
\end{abstract}

Change in the core attributes of organizations is difficult and fraught with peril. Organizational ecologists have proposed that when organizations change, resources are diverted from operating to reorganizing, which reduces efficiency and survival chances (Hannan and Freeman 1984, 1989; Amburgey et al. 1993; Barnett and Carroll 1995). These process effects of core change- the costs associated with redirecting resources from operations to reorganization, learning new routines, and building new relations with exchange partners-are expected to be negative. In contrast, the content effects of core change- the impact of adjusting to fit environmental demands-may be positive or negative, depending on the luck and skill of organizational decision makers and implementers. Considering process and content effects together, core organizational change is likely to impair performance and may even lead to failure.

Despite the inherent riskiness of core organizational change, it is sometimes necessary and occasionally beneficial. Organizational change can be precipitated by sudden, dramatic discontinuities in the environment, such as political upheavals, large-scale shifts in government regulation, and technological breakthroughs. Such environmental discontinuities, which punctuate periods of relative stability in organizational fields, can relocate or even obliterate boundaries between industries, rewrite the rules of competition and the norms of co-operation, and dramatically alter performance outcomes industrywide (Meyer et al. 1993). Such discontinuities disable organizations' routinized responses, plunging decision makers into strange and bewildering new worlds. They force organizations to adjust or face serious negative consequences and, therefore, increase the likelihood that the content effects of core organizational change will be positive (Meyer 1982, Zammuto 1988, Haveman 1992). 
Here, we examine the impact of one type of environmental discontinuity, regulatory punctuations, on the behavior and performance of hospitals and savings and loan associations in California. In doing so, we develop and test a model of organizational change and performance in the aftermath of punctuational regulatory change. Our model complements current thinking about organizational change and performance in stable and incrementally changing environments (Amburgey et al. 1993, Barnett and Carroll 1995). Our model also extends previous research on organizations' reactions to punctuational regulatory change (e.g., Fligstein 1990; Miner et al. 1990; Edelman 1990, 1992; Dobbin and Dowd 2000).

The final contribution of our paper is to redirect organizational theorists' attention to temporal issues. We show that two important organizational responses to regulatory punctuations, shifts in organizational domain and executive leadership, vary over time. We also show that the timing of organizations' responses to regulatory punctuations, particularly executive succession, moderates the impact of those responses on organizational performance.

\section{Punctuational Regulatory Change}

\section{The General Punctuated-Equilibrium Model}

Over the last three decades, punctuated-equilibrium models of change have taken their place alongside gradualistic models. Following the lead of scientists in evolutionary biology, chemistry, and physics, organizational theorists have reconceptualized change among individuals, groups, organizations, and industries. The older gradualist position maintained that change unfolds piecemeal through the accumulation of many small adjustments. The newer punctuated-equilibrium view maintains that short bursts of discontinuous change are interspersed between longer periods of relative stability (Eldredge and Gould 1972, Gould and Eldredge 1977). Punctuations follow gradual accumulations of stress, which systems resist until they reach their breaking points or until triggering events precipitate discontinuous change.

Organizational theorists who have adopted the punctuated-equilibrium perspective propose that organizational evolution has two distinct and recurring phases: (1) long periods of quasiequilibrium, during which organizations make only incremental changes in structure and activities, and (2) brief periods of disequilibrium, during which many new organizations appear and many existing ones are transmogrified (Tushman and Romanelli 1985, Tushman and Anderson 1986, Miner et al. 1990, Gersick 1991). Webs of symbiotic and commensalistic relations (Hawley 1950, pp. 33-65, Granovetter 1985) stabilize organizational communities between punctuations; these webs are sundered by punctuations.

The exogenous shocks that punctuate equilibria can create uninhabited or underexploited habitats where new forms of organization can thrive (e.g., Baum et al. 1995, Sine et al. 2001, Russo 2001); they may also collapse existing habitats (Tushman and Anderson 1986, Anderson and Tushman 1990). They can render permeable the boundaries separating existing industries and so abruptly alter the balance of blending and segregating mechanisms that impinge on organizational forms (Hannan and Freeman 1989 pp. 45-65). In sum, exogenous shocks make it possible for novel organizational mutations, intentional or random, to take hold.

Several forces may drive the sudden reordering of organizational environments. Astley (1985) argued that radical technological innovations restructure the contexts of competition and cooperation. Carroll (1987, p. 227) investigated social and political turmoil as sources of such punctuational changes and concluded that "exogenous punctuational change is probably more important, more pervasive, and more frequent than has been acknowledged by economists or organizational analysts." Romanelli (1989, pp. 225-226) argued that technological innovation, changes in government regulation, economic crashes, and sudden swings in social mores can all create or reconfigure resources to support new organizational activities.

In this paper, we focus on regulatory punctuations: sudden and extensive shifts in state constraints on business operations. Regulatory punctuations alter both technical and institutional features of organizational environments. They can alter technical environments by raising or lowering barriers to entry; e.g., deregulation in airlines in the 1970s and in telecommunications and financial services in the 1980s. They can also set prices or eliminate price controls, thereby altering profit formulae; e.g., deregulation of trucking in the early 1980s and electric utilities in the late 1990s. Regulatory punctuations can affect institutional environments by altering standards for accountability; e.g., rules for corporate financial reporting imposed when the Securities and Exchange Commission was founded in the 1930s, or requirements for reporting on human resources imposed by passage of Title VII of the Civil Rights Act in 1964. They can also sanction forms of organization; e.g., legislation in the 1930s that delegitimated trusts. Finally, they can modify relations between firms; e.g., passage of the Glass-Steagall Act in 1933, which erected barriers between commercial and investment banking, and passage of the Financial Services 
Modernization Act 1999, which basically annulled GlassSteagall. No matter what their content, large-scale regulatory changes trigger novel selection pressures that alter rewards and sanctions for organizational actions (Koza 1988, Wholey and Sanchez 1991).

Institutional theorists argue that organizations are driven by coercive isomorphic pressures to conform to the legal and cultural expectations of the state (Meyer and Rowan 1977, DiMaggio and Powell 1983). When major changes in regulations occur, these coercive pressures cause organizations to adjust their structures, processes, and strategies. Realignment with the shifting dictates of the state has been documented in a wide array of settings. One extended stream of work focuses on antitrust law. Over more than a century of history, American corporations have responded to antitrust laws through merger and acquisition. Antitrust legislation outlawing cooperation among firms generated a massive merger wave between 1898 and 1903 (Roy 1997). More specifically, Dobbin and Dowd (2000) demonstrated that a Supreme Court ruling in 1897 enforcing antitrust laws spawned a market for amicable (rather than predatory) mergers among Massachusetts railroads. Later in history, the Celler-Kefauver Act of 1950, which discouraged merger among firms in the same industry, caused firms to grow through crossindustry acquisition (Fligstein 1990). Finally, Stearns and Allan (1996) argued that each of the four waves of mergers in the 20th century followed a relaxation in antitrust enforcement.

Another large body of work examines firms' responses to changing legal conceptions of employee civil rights. American employers responded to the 1964 Civil Rights Act with a host of structural and practical actions. They instituted formal grievance procedures (Edelman 1990, Sutton et al. 1994) and established equal employment opportunity and affirmative action departments (Edelman 1992). They also developed policies that supported internal labor markets (Dobbin et al. 1993) and created specialized units to manage human resources issues, including antidiscrimination, safety, and benefits departments (Dobbin and Sutton 1998). More recently, following passage of the Pregnancy Leave Act of 1978 and the Family and Medical Leave Act of 1993, employers became increasingly likely to offer paid maternity leave (Kelly and Dobbin 1999, Guthrie and Roth 1999).

There has been some work on other types of regulatory punctuations. Mezias (1990) showed that the accounting practices of Fortune 200 companies vary in response to shifts in the policies of the Federal Accounting Standards Board, the Interstate Commerce Commission, and the Federal Power Commission. Miner et al. (1990) demonstrated that Finnish newspapers reacted to several exter- nal shocks, including changes in state laws and policies, by changing one or more organizational dimensions, including content, language, and editorship. Singh et al. (1991) found that voluntary social service organizations in Toronto adjusted their structures and goals in response to large-scale shifts in government funding. Most recently, Wade et al. (1998) showed how state laws prohibiting alcohol had ramifications not only for beer brewers in the focal state, but also for brewers in nearby states.

Taken together, the literature reviewed here indicates that many regulatory changes are large in magnitude and drive organizations to fundamentally alter their strategies, structures, and activities. But do large-scale regulatory changes create conditions that are unexpected, or can managers foresee their effects and plan accordingly? We address this question below.

\section{Unanticipated Consequences of Large-Scale Regulatory Change}

Major regulatory initiatives rarely come as a complete surprise; instead, they often arise from extensive public reflection, debate, and negotiation. Prolonged public discourse may facilitate affected companies' efforts to anticipate legislation. But anticipation of the timing and consequences of regulatory change can be only partial, for two reasons. First, many actions that organizations might take to prepare themselves for a new regulatory regime are barred until dates specified in legislation. Prior to such dates, affected organizations cannot finalize plans or implement change. For example, when the Airline Deregulation Act of 1978 was passed, airlines became free to enter and exit routes according to an explicit timetable set up in the act. Loosening of regulatory constraints took seven years, until the Civil Aeronautics Board was dismantled in 1985. According to one analyst, for this industry "the process of deregulation proved chaotic from the start" (Vietor 1989, p. 180) and was clarified only as much time passed. Between passage and full implementation of major legislation, many factors critical to performance can shift, further complicating attempts to plan and execute appropriate actions.

Second and more critical is the fact that large-scale regulatory change generates unintended outcomes (Merton 1936). Despite investments in predictive intelligence, industry incumbents tend to make incorrect forecasts about how major regulatory change will actually play out (Leone 1985). A classic case of the unanticipated consequences of major regulatory change occurred after the breakup of AT\&T. At issue was the question of whether AT\&T, which retained its long-distance, equipment, and research functions, would outperform its offspring, the seven "Baby Bells," which were to provide 
local telephone service. In the Yale Journal on Regulation, two prominent participants in the AT\&T divestiture proceedings argued that "[c]learly, AT\&T has won by losing, by having been left with the cream of its old services but with the restrictions on its ability to compete in those services removed" (MacAvoy and Robinson 1983, p. 42). Roughly 18 months later, the same authors returned to the pages of the same journal with a second article (MacAvoy and Robinson 1985), in which they outlined how state regulators unexpectedly asserted themselves after the breakup and blocked plans to increase local rates, forcing AT\&T to transfer long-distance revenues to local companies. Only at this point did it become clear that the Baby Bells, not AT\&T, would perform better after the breakup. That state commissions would play such an activist role came as a revelation to virtually all analysts and industry executives (MacAvoy and Robinson 1985 , p. 245). Thus, although it was the focus of widespread analysis and speculation, this regulatory punctuation propelled affected firms well beyond predicted bounds.

Regulatory change also can produce unexpected results by fostering shifts in competitive conditions that ex ante appear limited, but that later overwhelm predictions. One seemingly innocuous regulatory intervention that produced enormous change was one part of the Public Utilities Regulatory Policies Act (PURPA) of 1978. Among other, more widely noted statutes in PURPA was a law mandating that utilities purchase power from third-party producers at a price equal to the cost the utility would have incurred had it produced the electricity itself. In less than a decade, the number of third-party producers grew enormously (Russo 2001), and their role in the interorganizational community shifted from supplier to direct competitor (Joskow 1988).

In sum, although organizations affected by regulatory punctuations may act purposively, partial foresight and imprecise prediction of their impact generate substantial unintended consequences. The one sure thing is that conditions in a new regulatory regime will stabilize and become well understood only after a period of flux. Because of this, the aftermath of large-scale regulatory change can best be understood by applying a model of punctuated evolution.

\section{Regulatory Punctuations in Context: A Tale of Two Industries}

Regulatory regimes and regulatory punctuations vary greatly. Therefore, we cannot develop a general theory of the consequences of regulatory punctuations. Instead, we must develop mid range theories that are sensitive to context. Accordingly, this section describes in some detail the regulatory punctuations that occurred in our research sites, the hospital and the savings and loan industries. We chose to study these two industries because they experience strong pressures from both technical and institutional features of their environments (Scott 1998, p. 138, Table 6.2). Hence, organizations in both industries are likely to respond to major regulatory change. But, given clear differences in regulatory regime and content of regulatory punctuation, we expect interindustry differences in firm responses. A summary of our analysis appears in Table 1.

California Hospitals. The regulatory punctuation affecting California hospitals released pressures for change that had been accumulating for some time (Meyer et al. 1993) and triggered a rapid reconfiguration of the California healthcare sector. The first source of pressure was two decades of unabated growth in hospital costs (Melnick and Zwanziger 1988). The second pressure source was substantial excess capacity, the legacy of a hospital building boom fueled by federal largesse during the 1960s and 1970s.

In 1982, the California State Legislature released this pressure for change by enacting the nation's first managed-competition program. The expectation was that healthcare costs could be contained by unleashing market forces. To this end, the legislature created incentives for healthcare providers to compete on price. They also dismantled the Certificate-of-Need review process, which had protected established providers from competition. Nonhospital entrepreneurs were now free to compete with hospitals by offering selected services at lower prices. Meanwhile, the federal government phased in a new prospective-payment system, in which Medicare reimbursed providers according to predetermined rates tied to patient diagnoses, rather than cost-plus reimbursement. In sum, falling reimbursement rates squeezed hospitals' profit margins.

These changes eroded boundaries separating three distinct sectors: acute-care hospitals, health-care financing, and independent and group-practice medicine. Many organizations found themselves in unfamiliar and hostile terrain: As hospitals set up primary-care clinics, they invaded doctors' traditional turf; as insurers were transformed into health-maintenance organizations (HMOs), they confronted the complexities of actually delivering care; and as doctors signed preferred-provider contracts, they assumed unaccustomed financial risk.

California Savings and Loan Associations. The field in which savings and loan associations (thrifts) operatethe financial-services sector-contains myriad institu- 
Hospitals

- The Certificate-of-Need program is eliminated.

- Sealed-bid contracting is required for low-income patients.

- The prospective-payment system is initiated.

Savings \& Loans
- Restrictions on savings-account interest rates (Regulation Q) are phased out.

- Restrictions on thrifts' investments outside of the traditional residential mortgage market are reduced (but not eliminated).
- Barriers to entry are removed by the elimination of the CON program.

- Regional health networks form.

- Boundaries between medical practice, insurance, and hospital industries erode

- Sealed-bid contracting and prospective payment cut revenues and increase risk.

- Competition intensifies.

- Uncertainty about the optimal product/client portfolio increases as restrictions are reduced on both the asset and the liability sides of thrifts' balance sheets.

- Boundaries between thrifts and other financial-services industries erode.

- Competition intensifies. tions, including commercial and savings banks, credit unions, insurance companies, and securities firms. Boundaries between financial services institutions disintegrated when policy makers rewrote the sector's competitive rule book. Federal legislation passed in 1980 and 1982 opened up a multitude of new markets for federally chartered thrifts, providing them with opportunities to expand beyond their original domain (residential mortgage lending) and to compete more directly with other financial-services firms. In California, state legislation passed in January 1983 mirrored the opportunities created by federal legislation. For instance, the new laws authorized thrifts to invest up to $45 \%$ of their assets in consumer loans, up to $10 \%$ of assets in each of commercial loans and corporate debt securities, and up to $40 \%$ of assets in nonresidential mortgage loans.

Hailed by industry analysts as monumental and fundamental (McLean 1980, pp. 4-5; Carron 1983, pp. 1617), these deregulatory initiatives transformed thrifts' competitive environment from placid and constrained to uncertain and volatile. Deregulation eroded the oncereliable spread between interest paid on savings accounts and interest earned from mortgage loans-thrifts' cost of and return on funds, respectively. Interest-rate volatility exacerbated this trend. The effects of deregulation were amplified by technology. Advances in computer technology decreased time buffers and squeezed thrifts' profits, increased the number and complexity of thrifts' financial products, and increased thrifts' economies of scale and scope, making it advantageous for them to offer a wide array of services. Finally, the effects of thrift deregulation were intensified by pressure from banks and securities firms, which competed more closely with thrifts.

Summary. The California hospital and thrift industries experienced different kinds of regulatory punctuations and thus different types of selection pressures prevailed in the post-punctuation environments. Hospitals saw deregulation of prices and entry that together squeezed profit margins. In contrast, thrifts saw deregulation of scope of operations that offered the prospect of enhanced profits, balanced by increased competition from banks and securities firms.

\section{Organizational Responses to Regulatory Punctuations}

Among the set of actions available to organizations trying to respond to regulatory punctuations, three have been singled out for special attention: changes in domain, executive leadership, and performance. Radically new environmental conditions call for new leadership and for dramatic shifts in activities (Keck and Tushman 1993). Performance changes can trigger organizational change when performance declines due to misalignment between organizations and post-punctuation conditions. Performance changes can also result from changes in domain and leadership that are intended to adapt organizations to post-punctuation conditions.

The flux created by regulatory punctuations tends to dissipate gradually, in contrast to the flux created by technological punctuations, which are often truncated by the emergence of dominant designs (Anderson and Tushman 1990). Over time, interdependencies between regulated 
organizations and their customers, suppliers, and regulators stabilize as dense organizational communities develop (DiMaggio and Powell 1983, Shepherd 1985). Such structural interdependence may enable regulated firms to eventually "capture" their oversight agencies (Bernstein 1955); regulatory capture bolsters industry stability. As time passes, regulated industries also undergo processes of social construction that dampen fluctuations in their activities and structures (DiMaggio and Powell 1983, Jepperson 1991).

Below, we rely on two lines of reasoning to develop temporally-sensitive hypotheses about the aftermath of regulatory punctuations. Thinking about the novel competitive situation created by a regulatory punctuation leads us to predict effects that are exhibited immediately (direct effects) and effects that appear as time passes, firms react to the punctuation, and various industry sectors become crowded (indirect effects). Thinking about organizational learning leads us to predict effects that appear as time passes and organizations learn from their own and others' reactions to the punctuation (indirect effects). Hence, all of our hypotheses involve both immediate impacts of a regulatory punctuation and impacts that appear as time passes and the affected industry emerges from flux.

The Impact of Regulatory Punctuations on Organizational Domains. When a regulatory punctuation creates price competition or dismantles barriers to entry, firms often exhibit initial threat-rigidity reactions (Staw et al. 1981). Managers postpone taking action (Starbuck et al. 1978). As conditions deteriorate, they deny the severity of the mounting crisis and work instead to enhance the efficiency of core businesses. Accordingly, in the short run, we expect regulatory punctuations that reduce price supports or entry barriers will prompt firms to focus on their core businesses, strive to increase efficiency, and exit peripheral domain sectors. Only later, as profit margins are squeezed and easily attainable efficiencies have been achieved, do we expect firms to search for new product lines or market segments.

Research on organizational learning (e.g., Cyert and March 1963, Levinthal and March 1993) offers another reason why organizations will contract rather than expand their domains immediately after a regulatory punctuation that threatens profit margins. When performance declines below expectations, decision makers tend to search locally at first, to exploit current competencies. Only later, in the face of repeated poor performance, do they shift strategy and seek to explore new domains that require developing new competencies.

Taken together, these lines of reasoning suggest the following hypothesis:
HYPOTHESIS 1. Following a regulatory punctuation that cuts profit margins or lowers entry barriers, organizations will contract their domains; however, they will reverse direction and expand their domains as time passes.

In contrast, regulatory punctuations that broaden firms' allowed scope of operations create immediate opportunities for domain expansion. Prior to this kind of event, significant business opportunities may have been out of reach simply because regulated organizations were barred from operating in some sectors. But by following this kind of event, affected organizations become free to apply current competencies to the needs of new customers in new product or regional markets. Thus, regulated firms will expand their domains by moving into new lines of business immediately following the regulatory punctuation.

Organizational learning theory has something to say about this situation, too. Following a regulatory change that broadens firms' allowed scope of activities, the search for new, nearby sectors to exploit with current competencies will commence immediately, assuming that this kind of regulatory punctuation unleashes the pentup energies of the affected firms. Over time, organizations in the affected industry will learn, from their own experience and from the experience of others, which newly-opened domain sectors are profitable (Miner and Haunschild 1996). Thus over time, profitable new domain sectors will become crowded. Crowding will reduce incentives to enter those sectors, and the pace of domain expansion will slow.

HyPOTHESIS 2. Following a regulatory punctuation that increases the allowed scope of operations, organizations will expand their domains; however, domain expansion will slow as time passes.

The Impact of Any Regulatory Punctuation on CEO Succession. Executive succession can impart new knowledge and skills that make it possible to cope with the dramatic shifts in critical contingencies that follow regulatory punctuations (Thompson 1967, Pfeffer and Salancik 1978, Boeker 1997). If current executives are not willing or able to pilot their organizations through the new competitive channels, organizations will search for new talent. Executive succession also has symbolic value, as it projects an aura of change in organizational direction. When uncertainty mounts, yesterday's leaders tend to be seen as having caused today's crises, and their replacement symbolizes salvation and renewal (Gamson and Scotch 1964). The appointment of a new CEO can signal to external and internal audiences the intent to redirect, 
restructure, and revitalize an organization (Starbuck et al. 1978, Pfeffer 1981).

Both kinds of regulatory punctuation experienced by the industries we study here-those that lower prices or entry barriers and those that broaden the allowed scope of operations-place enormous pressure on managers. Consider each kind of event in turn. First, failure to thrive in the more competitive conditions that follow price and entry deregulation often leads to scapegoating and executive turnover (Gamson and Scotch 1964). And as time passes, regulated organizations will search for higher margins in more defensible unregulated niches, which further fuels demand for new people in the top ranks. Second, regulatory punctuations that remove constraints on regulated organizations' scope of operations open doors to markets that promise higher profits or growth potential. Because incumbent executives typically lack experience in these new markets, organizations often must recruit new ones. Thus in both situations, executive succession unfreezes norms and alters power distributions thereby facilitating the strategic reorientation needed to adapt to post-punctuation conditions (Virany et al. 1992). There is some empirical evidence to support the proposition that organizations are prone to change CEOs after regulatory shocks (Miner et al. 1990, Singh et al. 1991).

Working against this is the fact that organizational power distributions tend to be stable (Pfeffer 1982, pp. 289-332). Possessing power at one point in time facilitates retaining power because key actors easily acquire resources on which to base their subsequent powerholding. Even if CEOs have trouble acquiring resources in the new post-punctuation context, the resources and legitimacy that accrued to the CEO and firm during the prior regulatory regime dissipate slowly. Additionally, in established firms, beliefs about power distributions become institutionalized and uncritically accepted, reducing their chance of being challenged (Selznick 1949, Zucker 1977), even when external circumstances change dramatically. Finally, repeated failure to meet performance goals may be needed to convince decision makers to explore new domains rather than exploit current ones (Cyert and March 1963, Levinthal and March 1993). Exacerbating this tendency is the fact that CEOs who forged outmoded strategies often defend them and conceal the symptoms of deteriorating performance to retain their positions.

Considering all these factors together, we expect that CEO succession rates will rise only gradually in the wake of any regulatory punctuation, whether it presents a threat to profitability in current domain sectors (by lowering prices and entry barriers), or it presents an opportunity to enter new and potentially more profitable sectors (by removing constraints on markets served).

HYPOTHESIS 3. Immediately following any regulatory punctuation, CEO succession rates will not rise; instead, CEO succession rates will rise gradually as time passes.

\section{The Performance Consequences of Organizational Responses to Regulatory Punctuations}

Previous research on the performance consequences of organizational change (Amburgey et al. 1993, Barnett and Carroll 1995) predicts that the change process harms performance and increases the risk of organizational failure; however, these deleterious process effects are expected to diminish as time passes. Previous research also suggests that the content effects of change can be beneficial or harmful; in any case, these content effects are presumed to be constant in magnitude over time.

This theory makes the implicit assumption that organizational environments are stable or changing incrementally. Selection pressures are assumed to have been acting over time to force the adaptation or failure of organizations whose structures and strategies do not fit environmental demands. In contrast, the theory we develop here allows that environmental conditions-in particular, regulatory regimes-may shift suddenly and dramatically. Because punctuational regulatory change radically reorders environments and unleashes novel selection pressures, organizations must respond promptly or risk severe performance penalties (Haveman 1992). Only by changing core operations or entering new domain sectors will organizations discover configurations that suit the new, post-punctuation conditions.

Organizations that try to adapt to regulatory punctuations face a dual challenge: They must do the right things, and they must do them at the right time. In terms of content, actions appropriate to the new competitive environment must be identified and undertaken. In terms of process, these actions must be timed and sequenced carefully.

Domain Change. As noted above, we expect that the effectiveness of changing organizational domain is context-dependent. A regulatory punctuation that lowers entry barriers or squeezes profit margins threatens firms' core businesses. Retrenching (seeking increased efficiency in core businesses) is an appropriate initial response. Affected organizations' domains will not expand immediately after such a regulatory punctuation; they may even contract if firms exit businesses that have become unprofitable. Firms that retrench promptly are likely to outperform firms that try to weather the storm, deny the need for action, or postpone action as losses mount 
and cash reserves dwindle (Starbuck et al. 1978). As time passes, however, the benefits of retrenchment and restructuring core businesses will be tapped out. As firms adjust to the new environment, the negative effects of domain expansion should diminish. Organizations will gradually learn, from their own experience and from the experience of other firms (Miner and Haunschild 1996), which markets are profitable. Accordingly, we hypothesize:

HYPOTHESIS 4. Following a regulatory punctuation that lowers entry barriers or profit margins, domain expansion will harm firm performance; however, this negative effect will diminish as time passes.

When regulatory change expands organizations' allowed scope of operations, the situation is very different. Such change releases pent-up pressure to enter markets that were previously off-limits and seize profit opportunities there. Agile organizations can often seize firstmover advantages. Under these circumstances, expanding quickly is more likely to improve performance than retrenching or maintaining the status quo. Opportunities for effective domain expansion following this kind of regulatory punctuation may be temporary, however. Organizations have very short periods of time during which they can garner legitimacy for new forms of action (Ancona and Chong 1996). And as organizational and populationlevel learning about the new environment accumulates, organizations will converge on suitable configurations, and the benefit of further experimentation with new lines of business will diminish (Miner and Haunschild 1996). In other words, these organizations eventually re-enter the world described by ecologists (Amburgey et al. 1993, Barnett and Carroll 1995), in which the deleterious process effects of organizational change outweigh the beneficial content effects. Further domain changes are apt to become less beneficial as knowledge accumulates about what strategies are appropriate in the new regulatory regime, and as more organizations adopt appropriate strategies.

Research on technological punctuations supports this logic. Anderson and Tushman (1990) found that periods of industry ferment triggered by technological breakthroughs were relatively brief. Eisenhardt's (1989) work on industries that are frequently shaken by technological breakthroughs demonstrated that firms making rapid strategic decisions outperform slow-moving competitors. In a similar vein, Tyre and Orlikowski (1994) reported that improvements triggered by process innovations decline abruptly after a short introduction period.

In sum, we expect the benefits of domain change following a regulatory punctuation that broadens firms' allowed scope of operations to be greatest soon after the punctuation occurs and to diminish with the passage of time. If organizations postpone action, caches of slack resources will be consumed and competitors will preempt new market opportunities.

HyPOTHESIS 5. Following a regulatory punctuation that expands the allowed scope of operations, domain expansion will improve firm performance; however, this positive effect will diminish as time passes.

CEO Succession. While the need for domain expansion depends crucially on the content of the regulatory punctuation, the imperative for CEO succession does not. Regardless of the content of a regulatory punctuation, fresh faces and new knowledge in the executive ranks facilitate adaptation to post-punctuation conditions (Thompson 1967, Pfeffer and Salancik 1978, Virany et al. 1992, Boeker 1997). This should occur whether adaptive actions involve expansion into new sectors or efficiencyseeking retrenchment of operations. CEO succession also has symbolic value, as it signals intentions to redirect, restructure, and revitalize an organization (Starbuck et al. 1978, Pfeffer 1981) following a regulatory punctuation.

The benefits of post-punctuation CEO succession will, however, be greatest soon after the punctuation occurs and will diminish with the passage of time. As with opportunities for effective domain change, opportunities for effective executive succession are short lived. As time passes, knowledge concerning the new regulatory regime accumulates (Miner and Haunschild 1996), affected organizations converge on suitable strategies, and the benefit of further experimentation by new leaders diminishes. Thus the deleterious process effects of executive succession will eventually overwhelm the beneficial content effects.

HYPOTHESIS 6. Following any regulatory punctuation, CEO succession will improve firm performance; however, this positive effect will diminish as time passes.

We predicted above (Hypothesis 3) that organizations will not experience higher rates of CEO succession immediately following a regulatory punctuation; instead, CEO succession rates will rise gradually after a regulatory punctuation. This seems to contradict Hypothesis 6 . But the contradiction is apparent, not real. CEO succession may be needed to bring the skill and knowledge of regulated organizations in line with their new environments, but the inertia inherent in organizational power structures may mitigate against such timely responses.

\section{Research Design}

To test these hypotheses, we gathered longitudinal archival data on hospitals and thrifts in California. Our primary 
data sources were the California Health Facilities Commission/Office of Statewide Health Planning and Development data tapes (for hospitals) and the Federal Home Loan Bank Board data tapes (for thrifts). Our data cover 119 private, nonprofit general acute-care hospitals from 1978 to 1991 and 216 thrifts from 1977 to 1986.

Sampling Frame. Our sample of thrifts constitutes the entire population during our study period. Our sample of hospitals is a little more restricted. First, it excludes psychiatric and other specialty hospitals because such niche providers were subject to very different market and institutional forces than were general hospitals. Our sample also excludes proprietary, investor-owned hospitals because most are not autonomous entities but units of national chains whose corporate parents make many key strategic decisions for them. The corporate parents of investor-owned hospital chains were often based out of state; hence, decision makers at corporate headquarters were less sensitive to events occurring in California. Another reason for excluding investor-owned hospitals is that the data available on such organizations is of significantly lower quality than the data available on their nonprofit counterparts.

\section{Model Specification and Estimation}

We test hypotheses about domain expansion and performance with multiple regression on pooled time-series data. The model we estimate is:

$$
Y_{t_{1}}=\alpha Y_{t_{0}}+\beta^{\prime} X_{t_{0}}+\epsilon,
$$

where $Y_{t_{1}}$ is the value of the outcome variable (domain or performance) at the end of a period, $Y_{t_{0}}$ is the value of this variable at the start of the period, and $X_{t_{0}}$ is a vector of time-varying explanatory variables measured at the start of the period. We used the AUTOREG procedure in SAS (SAS Institute 1993). To correct for first-order, within-firm autocorrelation, we "stacked" the data, sorting by firm and year; at the end of each firm's time series, we added a record with missing data for all variables except firm identification number and year (SAS technical consultant, personal communication 1998). The AUTOREG correction for autocorrelation uses a generalized leastsquares approach based on the Yule-Walker method, as described by Gallant and Goebel (1976). AUTOREG also allowed us to adjust for the presence of lagged dependent variables. Finally, we also corrected for heteroskedasticity, using a correction described in Bollerslev (1986), which estimates error variances that can vary over time and across firms.

We test hypotheses about CEO succession using eventhistory analysis. Our dependent variable is the instantaneous rate of CEO succession:

$$
r_{t}=\lim _{d t \downarrow 0} \frac{\operatorname{Pr}(t \leq T<t+d t \mid T \geq t)}{d t},
$$

where $r_{t}$ is the hazard rate of CEO succession at time $t$, $\operatorname{Pr}($.$) is the probability of succession between times t$ and $t+d t$. Any firm in our sample can experience multiple succession events, so we use a repeated-events framework in which the dependent variable incorporates information from all successions, not just the first. Job mobility, including the turnover of top executives, is generally modelled as a semi-Markov process (e.g., Tuma 1976). For such processes, the rate of transition depends only on the nature of the current state (here, the current organization) and time in state (here, CEO tenure). Accordingly, we used the maximum-likelihood program RATE (Tuma 1993) to estimate models of the following form:

$$
r_{t}=\exp \left[\beta^{\prime} X_{t}+\gamma t\right]
$$

where $X_{t}$ is a vector of time-varying explanatory variables and $t$ is a time clock (CEO tenure).

The outcomes we study - changes in domain, leadership, and performance-are embedded in a complex system of relationships. Good performance solidifies incumbent executives' positions (Harrison et al. 1988, Boeker 1992). Regulatory punctuations degrade performance and prompt CEO succession (Singh et al. 1991), whether for technical reasons (Grusky 1963) or because of ritual scapegoating (Gamson and Scotch 1964). New executives are inclined to change their firms' domains because new talent brings with it new ideas, competencies, and political connections (Pfeffer and Salancik 1978, Boeker 1997). Such domain changes sometimes yield improvements in performance (Guest 1962, Singh et al. 1986, Virany et al. 1992).

The circularity in this causal system complicates empirical analysis. Moreover, the implied sequence could be reversed; for instance, windfall profits could underwrite movement into new domains that demand different knowledge and skills in the chief executive. Temporal ordering of events is key to disentangling cause and effect. To isolate any particular relationship, one must collect longitudinal data and control for prior organizational and environmental changes. In particular, one must control for prior performance and CEO succession in models of domain expansion, for prior performance and domain change in models of CEO succession, and for prior performance and CEO succession in models of performance. ${ }^{1}$

\section{Measures}

The regulatory punctuations occurred in 1982 for both hospitals and thrifts, when the California Legislature enacted the nation's first comprehensive managedcompetition program, and the Garn-St. Germain Act 
passed by federal regulators substantially broadened thrifts' investment powers. We followed Amburgey et al. (1993) in using two variables to capture the effect of these regulatory punctuations. A regulatory punctuation indicator captures immediate effects; it starts takes an initial value of zero and shifts to one in 1983, the year after the punctuation occurred. A regulatory punctuation time clock captures effects that emerge as time passes; it equals zero up to and including 1982; it shifts to one in 1983 and rises by one each subsequent year.

We measured domain expansion as the one-year change in scope of operations. For hospitals, we counted services offered, out of 135 categories (Goes and Park 1997). For thrifts, we measured the spread of investments in eight markets (Haveman 1992), calculated as $H_{i}=$ $\Sigma_{m}\left(P_{i m}\right)^{2}$, where $P_{i m}$ is the proportion of assets firm $i$ has invested in market $m$ (Blau 1977). For thrifts, we also measured activity in new lines of business as the proportion of assets invested in seven categories: nonresidential mortgages, consumer loans, commercial loans, mortgagebacked securities, real estate, investment securities, and service companies (Haveman 1992). ${ }^{2}$

We measured $C E O$ succession with an indicator set equal to one year after a new top executive arrived and zero otherwise. In the year of a succession event, the outgoing CEO was coded as being in office for the entire year. Because a new CEO generally needs some time to become established, this coding scheme matched actual conditions better than coding the new CEO as serving all year long. ${ }^{3}$

For hospitals, we measured performance as return on sales (gross patient-services revenue over net income), which reflects both effectiveness (good choices about services to offer) and efficiency (low cost) (Goes 1989). Return on sales is preferable to return on assets because hospitals vary in their asset intensity, depending on the services they provide. For savings and loans, we used return on assets; this is the best measure of performance for this industry, which contains both joint-stock and mutual companies (Cole 1971).

We tested for the immediate effects of domain change and CEO succession on performance with the postpunctuation domain change and CEO succession variables described above. To test for effects that emerge as time passes, we followed Amburgey et al. (1993) and created interactions between the regulatory-punctuation time clock and post-punctuation domain change and CEO succession. For domain change, we multiplied post-punctuation domain change by the regulatory-punctuation time clock. For thrifts, we used both overall scope of operations and activity in new lines of business; for hospitals, we used overall scope of operations only. For CEO succession, we created a variable indicating the first post-punctuation CEO succession, which was set to zero up to and including the year of the first post-punctuation succession event and one afterward. We then multiplied this first postpunctuation succession variable by the regulatorypunctuation time clock.

Our models also include control variables. We first dealt with bidirectional causation. Models of domain change include controls for prior-year performance relative to the industry mean and prior-year CEO succession. Models of CEO succession include controls for prior-year performance relative to the industry mean and prior-year domain change (one-year change in scope of operations). And, of course, models of performance include, as theoretical variables, post-punctuation domain change and CEO succession.

Our exogenous control variables include three that have been found to be important by previous research: organizational size, measured as the natural logarithm of beds for hospitals and as assets for thrifts (in millions of dollars); growth, measured as the one-year change in sales for hospitals and the one-year change in assets for thrifts; and the natural logarithm of organizational age in both industries (in years). Our models also included macroeconomic indicators that are specific to each industry. For hospitals, we used the one-year change in GNP, to account for general economic conditions; for thrifts, we used the gap between short- and long-term interest rates to capture the spread between interest earned from shortterm deposits and interest paid on long-term mortgage loans. Finally, following previous research, our analysis of CEO succession included $C E O$ tenure, measured as number of years of service, beginning with the first full year in office. CEO tenure is reset to zero by each succession event.

In our analysis of thrift performance, we were confronted by possible sample-selection bias due to failure. (We faced no such problem with hospitals because none failed during our observation period.) If thrifts that change domain are likely to perform poorly and fail, as predicted by Hannan and Freeman (1984), they will leave the sample without their last-year domain change affecting the estimates on performance. This selection bias can be captured by a parameter $(\lambda)$, which is the likelihood of failure predicted by organizational and environmental factors (Heckman 1979). Accordingly, we estimated thrift failure using variables taken from previous research: density and its square, performance, growth, size, and age. We then added the sample-selection parameter $\lambda$ to regressions for thrift performance. 


\section{Results}

Tables $2 \mathrm{a}$ and $2 \mathrm{~b}$ provide descriptive statistics for all variables in our analyses of hospitals and thrifts, respectively. Although some correlations are statistically significant, none of the correlations among the measures of the punctuation, domain expansion, succession, or performance are extraordinarily high. The two variables that we used to measure the effects of regulatory punctuations correlate relatively highly in both samples; hence, collinearity might be a problem. Unfortunately, the AUTOREG procedure does not yield collinearity test statistics. To get around this problem, we ran OLS regressions to estimate domain expansion and performance, using the variables shown in Table 3 (Models 1, 3, and 5) and Table 5 (Models 1 and 3). To assess collinearity, we examined the condition indices generated by SAS. According to Belsley et al. (1980), there is cause for concern if a condition index exceeds 30 . The maximum condition index for the regulatory variables in our models was 13.7 ; hence, we concluded that collinearity did not degrade results from the AUTOREG procedure.

\section{Domain Change}

Our analysis of domain change is shown in Table 3. Recall that for thrifts, we analyze overall scope of operations and level of activity in new lines of business, while for hospitals, we analyze overall scope of operations only, due to data limitations. Model 1 is a baseline model for hospitals; Model 2 tests Hypothesis 1, which predicts that hospitals will not expand their domains immediately after the regulatory punctuation, but will instead expand gradually as time passes. The estimate on the punctuation indicator is negative, while the estimate on the time clock is positive. This means that hospitals contracted their domains immediately after the regulatory punctuation, and then gradually expanded, which supports Hypothesis 1. Comparing the coefficient on the punctuation indicator with the coefficient on the time clock shows that it took roughly five years for the typical hospital to attain a broader domain than in the prepunctuation regulatory regime $(4.09 / 0.807=5.1$ years to overcome the negative immediate effect of the punctuation). Turning to the controls, we see that large hospitals typically expanded their operations more than small ones and that CEO succession dampened expansion. GNP had a positive effect, indicating that hospitals diversified when economic conditions were favorable.

Models 3 through 6 test Hypothesis 2, which predicts that thrifts will expand their domains immediately after the regulatory punctuation, but that expansion will slow as time passes. Models 3 and 4 show results for thrifts' overall scope of operations; Model 3 contains only controls, while Model 4 adds independent variables. As expected, we see very different results than for hospitals. In

Table 2a

Means, Standard Deviations, and Correlations for Hospitals

\begin{tabular}{|c|c|c|c|c|c|c|c|c|c|c|c|c|c|}
\hline & 1 & 2 & 3 & 4 & 5 & 6 & 7 & 8 & 9 & 10 & 11 & 12 & 13 \\
\hline Mean & 0.69 & 3.46 & 82.3 & 0.16 & 3.89 & 5.17 & 13.8 & 44.00 & 1.54 & 0.16 & 0.00 & 3.52 & 7.82 \\
\hline Standard Deviation & 0.46 & 3.15 & 23.4 & 0.37 & 4.68 & 0.71 & 29.1 & 85.59 & 8.45 & 0.37 & 4.44 & 2.89 & 6.89 \\
\hline 1. Regulatory Punctuation & & & & & & & & & & & & & \\
\hline $\begin{array}{l}\text { Indicator Variable } \\
\text { 2. Time Since }\end{array}$ & & $0.732^{*}$ & $0.224^{*}$ & $0.084^{\star}$ & -0.043 & 0.032 & $-0.119^{\star}$ & 0.035 & 0.058 & 0.036 & 0.000 & $0.479^{\star}$ & -0.020 \\
\hline Regulatory Punctuation & & & $0.323^{*}$ & $0.079^{\star}$ & $-0.207^{\star}$ & 0.035 & $-0.112^{*}$ & $0.043^{*}$ & $0.098^{*}$ & $0.091^{*}$ & 0.000 & $-0.065^{\star}$ & $-0.079^{*}$ \\
\hline 3. Scope of Operations & & & & -0.036 & -0.022 & $0.646^{*}$ & -0.006 & $-0.109^{*}$ & $0.222^{*}$ & -0.036 & $0.063^{*}$ & $-0.057^{\star}$ & -0.033 \\
\hline 4. CEO Succession & & & & & $-0.163^{\star}$ & $-0.081^{*}$ & $0.051^{*}$ & $0.139^{*}$ & 0.025 & $0.199^{*}$ & $-0.167^{\star}$ & $0.078^{*}$ & $-0.097^{\star}$ \\
\hline 5. Performance & & & & & & $0.160^{\star}$ & $0.085^{*}$ & $-0.074^{*}$ & 0.010 & $-0.119^{*}$ & $0.501^{*}$ & $0.153^{*}$ & $0.181^{*}$ \\
\hline 6. Organizational Size & & & & & & & -0.014 & $-0.103^{*}$ & 0.035 & $-0.083^{*}$ & $0.160^{*}$ & 0.003 & $0.069^{*}$ \\
\hline 7. Organizational Growth & & & & & & & & -0.021 & -0.009 & 0.034 & -0.041 & $-0.078^{*}$ & -0.008 \\
\hline 8. Organizational Age & & & & & & & & & -0.009 & $0.140^{\star}$ & -0.068 & 0.001 & $-0.083^{\star}$ \\
\hline 9. Prior-Year Domain & & & & & & & & & & & & & \\
\hline Expansion (Scope of Ops) & & & & & & & & & & -0.039 & $0.067^{*}$ & -0.028 & 0.001 \\
\hline 10. Prior-Year CEO & & & & & & & & & & & & & \\
\hline Succession & & & & & & & & & & & $-0.149^{*}$ & -0.001 & -0.437 \\
\hline 11. Prior-Year Performance & & & & & & & & & & & & & \\
\hline Relative to Industry Avg. & & & & & & & & & & & & 0.000 & $0.196^{*}$ \\
\hline 12. Macroeconomic Factor & & & & & & & & & & & & & 0.027 \\
\hline 13. CEO Tenure & & & & & & & & & & & & & \\
\hline
\end{tabular}

Note. This table shows descriptive statistics for 1,547 firm-observations on hospitals. ${ }^{*}$ indicates $p<0.05$. 
HEATHER A. HAVEMAN, MICHAEL V. RUSSO, AND ALAN D. MEYER Organizational Environments in Flux

\begin{tabular}{|c|c|c|c|c|c|c|c|c|c|c|c|c|c|c|}
\hline & 1 & 2 & 3 & 4 & 5 & 6 & 7 & 8 & 9 & 10 & 11 & 12 & 13 & 14 \\
\hline Mean & 0.43 & 1.04 & 0.51 & 0.32 & 0.15 & 0.01 & 695.6 & 0.42 & 31.91 & 0.03 & 0.17 & 0.00 & 1.11 & 7.63 \\
\hline Standard Deviation & 0.49 & 1.41 & 0.16 & 0.18 & 0.35 & 0.03 & 1940. & 1.62 & 29.07 & 0.10 & 0.38 & 0.26 & 2.31 & 7.18 \\
\hline $\begin{array}{l}\text { 1. Regulatory Punctuation } \\
\text { Indicator Variable } \\
\text { 2. Time Since }\end{array}$ & & $0.858^{*}$ & $0.605^{\star}$ & * $0.542^{*}$ & $0.141^{\star}$ & -0.006 & $0.102^{*}$ & $0.069^{*}$ & $-0.108^{*}$ & 0.044 & $0.058^{\star}$ & 0.000 & $0.609^{*}$ & $-0.086^{\star}$ \\
\hline $\begin{array}{l}\text { Regulatory Punctuation } \\
\text { 3. Scope of Operations }\end{array}$ & & & $0.545^{\star}$ & $\begin{array}{l}0.471^{*} \\
0.836^{*}\end{array}$ & $0.149^{\star}$ & $\begin{array}{l}-0.018 \\
-0.079^{*}\end{array}$ & $\begin{array}{l}0.113^{*} \\
0.084^{*}\end{array}$ & $\begin{array}{r}-0.031 \\
0.106^{*}\end{array}$ & $\begin{array}{l}-0.079^{*} \\
-0.116^{*}\end{array}$ & $\begin{array}{r}-0.103^{*} \\
0.290^{*}\end{array}$ & $\begin{array}{l}0.054 \\
0.125^{\star}\end{array}$ & $\begin{array}{r}0.000 \\
*-0.009\end{array}$ & $\begin{array}{l}0.466^{*} \\
0.543^{*}\end{array}$ & $\begin{array}{l}-0.068^{\star} \\
-0.095\end{array}$ \\
\hline $\begin{array}{l}\text { 4. Activity in New } \\
\text { Linesof Business }\end{array}$ & & & & & 0.166 & -0.032 & 0.015 & $0.202^{*}$ & $-0.199^{*}$ & 0.312 & $0.216^{*}$ & * $\quad 0.004$ & $0.497^{*}$ & $-0.171^{*}$ \\
\hline 5. CEO Succession & & & & & & $-0.127^{\star}$ & -0.021 & $0.126^{*}$ & $-0.114^{*}$ & 0.038 & 0.144 & -0.053 & $0.103^{*}$ & $-0.109^{*}$ \\
\hline 6. Performance & & & & & & & 0.034 & $0.076^{\star}$ & -0.009 & 0.001 & -0.045 & $0.377^{*}$ & $-0.147^{\star}$ & 0.002 \\
\hline 7. Organizational Size & & & & & & & & $-0.020^{*}$ & $0.350^{*}$ & -0.023 & $-0.076^{*}$ & * 0.019 & 0.053 & $0.159^{*}$ \\
\hline 8. Organizational Growth & & & & & & & & & $-0.183^{*}$ & 0.090 & $0.158^{\star}$ & * -0.019 & $0.123^{\star}$ & $-0.114^{*}$ \\
\hline 9. Organizational Age & & & & & & & & & & -0.056 & $-0.253^{*}$ & * -0.022 & $-0.125^{\star}$ & $0.409^{*}$ \\
\hline 10. Prior-Year Domain & & & & & & & & & & & & & & \\
\hline $\begin{array}{l}\text { Expansion (Scope of Ops) } \\
\text { 11. Prior - Year CEO }\end{array}$ & & & & & & & & & & & $0.186^{\star}$ & 0.046 & 0.149 & 0.060 \\
\hline $\begin{array}{l}\text { Succession } \\
\text { 12. Prior-Year Performance }\end{array}$ & & & & & & & & & & & & $-0.143^{*}$ & 0.101 & $-0.423^{*}$ \\
\hline $\begin{array}{l}\text { Relative to Industry Avg. } \\
\text { 13. Macroeconomic Factor } \\
\text { 14. CEO Tenure }\end{array}$ & & & & & & & & & & & & & 0.000 & $\begin{aligned} & 0.003 \\
- & 0.114^{*}\end{aligned}$ \\
\hline
\end{tabular}

Note. This table shows descriptive statistics for 1,301 firm-year observations on savings and loans. * indicates $p<0.05$.

Model 4, the punctuation indicator has a positive effect, as predicted, but it is nonsignificant; the time clock has a negative and significant effect, as predicted. At best, this provides partial support for Hypothesis 2: The average thrift's overall scope of operations did not change immediately after the regulatory punctuation, but the likelihood of expansion diminished with the passage of time. Models 5 and 6 show results for investments in new lines of business; again, Model 5 contains controls only while Model 6 adds independent variables. The results in Model 6 differ in important ways from those in Model 4. The regulatory punctuation indicator has a positive and significant effect, while the time clock has a negative and significant effect. This offers strong support for Hypothesis 2 . On average, it took nearly three years for thrifts to reduce entry into new lines of business to the level of the prepunctuation regulatory regime $(0.027 / 0.010=2.7$ years to exhaust the positive immediate effect of the punctuation). Among the controls, growth and better economic conditions (spreads between short- and long-term interest rates) both led thrifts to expand their domains. CEO succession led to greater overall scope of operations and organizational age had a positive relationship with new business activities.

The difference between results for the two measure of domain change can be explained easily. Immediately after the regulatory punctuation, many thrifts decreased their reliance on residential mortgages, their traditional product, and simultaneously increased their investments in new lines of business, such as consumer nonmortgage loans, commercial loans, and real estate (U.S. General Accounting Office 1991). Thus, we see immediate increases in investments in new lines of business, but no net increase in overall scope of operations.

\section{CEO Succession}

Table 4 tests Hypothesis 3, which states that CEO succession will not increase immediately after a regulatory punctuation but rather will increase gradually, as time passes. Model 1 is a baseline for hospitals, containing controls only; Model 2 adds independent variables. Consistent with Hypothesis 3, the coefficient on the regulatory punctuation is nonsignificant, and the coefficient on the time clock is positive and significant. Turning to the controls, CEO tenure was negatively related to succession, as expected from research on job mobility. Organizational age and economic conditions were positively related to succession. The effect of relative performance was negative, indicating that succession was more likely in poorly performing hospitals. 
HEATHER A. HAVEMAN, MICHAEL V. RUSSO, AND ALAN D. MEYER Organizational Environments in Flux

Table 3 The Effect of Regulatory Punctuations on Domain Expansion

\begin{tabular}{|c|c|c|c|c|c|c|}
\hline \multirow{3}{*}{$\begin{array}{l}\text { Industry } \\
\text { Aspect of Domain Expansion } \\
\text { Analyzed } \\
\text { Model \# }\end{array}$} & \multicolumn{2}{|c|}{ Hospitals } & \multicolumn{4}{|c|}{ Savings \& Loans } \\
\hline & \multicolumn{2}{|c|}{$\begin{array}{c}\text { Overall Scope of } \\
\text { Operations }\end{array}$} & \multicolumn{2}{|c|}{$\begin{array}{l}\text { Overall Scope } \\
\text { of Operations }\end{array}$} & \multicolumn{2}{|c|}{$\begin{array}{c}\text { Activity in New Lines } \\
\text { of Business }\end{array}$} \\
\hline & 1 & 2 & 3 & 4 & 5 & 6 \\
\hline Constant & $\begin{array}{r}2.52^{*} \\
(1.26)\end{array}$ & $\begin{array}{c}1.11 \\
(1.19)\end{array}$ & $\begin{array}{l}0.115^{\star * *} \\
(0.013)\end{array}$ & $\begin{array}{l}0.101^{* * \star} \\
(0.013)\end{array}$ & $\begin{array}{l}0.056^{\star \star \star} \\
(0.013)\end{array}$ & $\begin{array}{l}0.052^{\star \star \star} \\
(0.013)\end{array}$ \\
\hline Prior-Year Domain Expansion & $\begin{array}{l}0.942^{\star \star \star} \\
(0.012)\end{array}$ & $\begin{array}{l}0.918^{\star * \star} \\
(0.012)\end{array}$ & $\begin{array}{l}0.780^{* * *} \\
(0.021)\end{array}$ & $\begin{array}{l}0.828^{\star * \star} \\
(0.023)\end{array}$ & $\begin{array}{l}0.769 * \star \star \\
(0.020)\end{array}$ & $\begin{array}{l}0.782^{\star \star \star} \\
(0.021)\end{array}$ \\
\hline Organizational Size & $\begin{array}{l}1.01^{\star \star} \\
(0.321)\end{array}$ & $\begin{array}{l}1.54^{\star \star \star} \\
(0.297)\end{array}$ & $\begin{array}{c}0.0001 \\
(0.002)\end{array}$ & $\begin{array}{c}0.0002 \\
(0.002)\end{array}$ & $\begin{array}{r}-0.0007 \\
(0.002)\end{array}$ & $\begin{array}{c}-0.0003 \\
(0.006)\end{array}$ \\
\hline Organizational Growth & $\begin{array}{r}-0.007 \\
(0.011)\end{array}$ & $\begin{array}{c}-0.00008 \\
(0.013)\end{array}$ & $\begin{array}{l}0.003^{\star \star \star} \\
(0.0008)\end{array}$ & $\begin{array}{c}0.003^{\star * *} \\
(0.0009)\end{array}$ & $\begin{array}{c}-0.009^{\star \star \star} \\
(0.0007)\end{array}$ & $\begin{array}{l}0.008^{\star * *} \\
(0.001)\end{array}$ \\
\hline Organizational Age & $\begin{array}{r}-0.122 \\
(0.261)\end{array}$ & $\begin{array}{r}-0.300 \\
(0.234)\end{array}$ & $\begin{array}{c}0.002 \\
(0.002)\end{array}$ & $\begin{array}{c}0.002 \\
(0.002)\end{array}$ & $\begin{array}{r}0.006^{*} \\
(0.003)\end{array}$ & $\begin{array}{r}0.006^{\star} \\
(0.003)\end{array}$ \\
\hline $\begin{array}{l}\text { Prior-Year Performance Relative to } \\
\text { Industry Average }\end{array}$ & $\begin{array}{r}0.093^{*} \\
(0.046)\end{array}$ & $\begin{array}{c}0.074 \\
(0.045)\end{array}$ & $\begin{array}{r}-0.096 \\
(0.107)\end{array}$ & $\begin{array}{r}-0.088 \\
(0.106)\end{array}$ & $\begin{array}{r}0.250^{*} \\
(0.114)\end{array}$ & $\begin{array}{r}-0.087 \\
(0.113)\end{array}$ \\
\hline Prior-Year CEO Succession & $\begin{array}{r}-0.774 \\
(0.522)\end{array}$ & $\begin{array}{r}-1.23^{\star \star} \\
(0.476)\end{array}$ & $\begin{array}{l}0.014^{*} \\
(0.007)\end{array}$ & $\begin{array}{l}0.019 * * \\
(0.007)\end{array}$ & $\begin{array}{c}0.011 \\
(0.008)\end{array}$ & $\begin{array}{c}0.012 \\
(0.008)\end{array}$ \\
\hline Macroeconomic Factor & $\begin{array}{r}-0.105 \\
(0.057)\end{array}$ & $\begin{array}{l}0.258^{*} \\
(0.110)\end{array}$ & $\begin{array}{l}0.011^{* * *} \\
(0.001)\end{array}$ & $\begin{array}{l}0.013^{\star \star \star} \\
(0.001)\end{array}$ & $\begin{array}{l}0.012^{\star \star \star} \\
(0.001)\end{array}$ & $\begin{array}{l}0.011^{* * *} \\
(0.002)\end{array}$ \\
\hline Regulatory Punctuation Indicator Variable & & $\begin{array}{l}-4.09^{* * *} \\
(1.18)\end{array}$ & & $\begin{array}{l}0.0005 \\
(0.010)\end{array}$ & & $\begin{array}{l}0.027^{\star \star} \\
(0.010)\end{array}$ \\
\hline Time Since Regulatory Punctuation & & $\begin{array}{l}0.807^{* * *} \\
(0.134)\end{array}$ & & $\begin{array}{c}-0.010^{\star *} \\
(0.004)\end{array}$ & & $\begin{array}{c}-0.010^{\star *} \\
(0.004)\end{array}$ \\
\hline Log-likelihood & -4907.2 & -4879.89 & 1252.1 & 1260.8 & 1096.8 & 1104.3 \\
\hline
\end{tabular}

Note. These models were estimated on 1,547 firm-year observations on hospitals and 1,301 firm-year observations on savings and loans. These models tested and corrected for first-order autocorrelation. Standard errors are in parentheses below parameter estimates.

* indicates $p<0.05,{ }^{* \star} p<0.01$, and ${ }^{* \star *} p<0.001$, one-tailed $t$ tests for explanatory variables, two-tailed $t$ tests for control variables.

Models 3 and 4 show results for savings and loans; Model 3 is a baseline containing controls only, while Model 4 adds independent variables. The impact of the regulatory punctuation was not immediate but rather increased over time, offering further support for Hypothesis 3. Among the control variables, tenure was again negatively associated with CEO succession. Organizational growth was positively related to CEO succession, perhaps because growth took thrifts into areas where new CEOs were deemed necessary. Contrary to the case of hospitals, older thrifts were less likely to experience CEO succession.

The impact of the regulatory punctuation on CEO succession was much greater for thrifts than for hospitals. For each year after the punctuation, the hazard rate for
CEO succession among hospitals rose 10\% (exp[0.093] $=1.10)$; among thrifts, it rose $24 \%(\exp [0.212]=1.24)$.

Internal and external succession are different kinds of processes. We could distinguish internal and external succession for thrifts but not for hospitals. Therefore, we estimated a competing-risks models of internal vs. external succession for thrifts. We coded the dependent variable as zero if the focal thrift did not experience CEO succession, one if the new CEO was an insider, and two if he or she was an outsider. The result of this analysis is shown in Models 5 and 6 of Table 4. Briefly, these results show that the regulatory punctuation precipitated internal succession but not external succession. In Model 5, which shows results for internal succession, the estimate on the punctuation indicator is nonsignificant and the estimate 
HEATHER A. HAVEMAN, MICHAEL V. RUSSO, AND ALAN D. MEYER Organizational Environments in Flux

Table 4 The Effect of Regulatory Punctuations on CEO Succession

\begin{tabular}{|c|c|c|c|c|c|c|}
\hline \multirow{2}{*}{$\begin{array}{l}\text { Industry } \\
\text { Model \# }\end{array}$} & \multicolumn{2}{|c|}{ Hospitals } & \multicolumn{2}{|c|}{ Savings \& Loans } & \multicolumn{2}{|c|}{ S\&LS } \\
\hline & 1 & 2 & 3 & 4 & Inside Succn 5 & Outside Succn 6 \\
\hline Constant & $\begin{array}{c}-2.00^{\star \star \star} \\
(0.545)\end{array}$ & $\begin{array}{c}-2.10^{\star \star \star} \\
(0.551)\end{array}$ & $\begin{array}{c}-1.50^{\star \star \star} \\
(0.195)\end{array}$ & $\begin{array}{c}-1.69^{\star \star \star} \\
(0.215)\end{array}$ & $\begin{array}{c}-2.83^{\star \star \star} \\
(0.329)\end{array}$ & $\begin{array}{c}-2.04^{\star \star \star} \\
(0.415)\end{array}$ \\
\hline CEO Tenure & $\begin{array}{c}-0.026^{\star *} \\
(0.011)\end{array}$ & $\begin{array}{r}-0.023^{*} \\
(0.011)\end{array}$ & $\begin{array}{r}-0.025 \\
(0.014)\end{array}$ & $\begin{array}{r}-0.024 \\
(0.014)\end{array}$ & $\begin{array}{c}0.008 \\
(0.017)\end{array}$ & $\begin{array}{c}-0.096^{\star \star *} \\
(0.030)\end{array}$ \\
\hline Organizational Size & $\begin{array}{r}-0.171^{*} \\
(0.086)\end{array}$ & $\begin{array}{r}-0.177^{*} \\
(0.087)\end{array}$ & $\begin{array}{c}0.005 \\
(0.048)\end{array}$ & $\begin{array}{r}-0.009 \\
(0.048)\end{array}$ & $\begin{array}{c}0.002 \\
(0.058)\end{array}$ & $\begin{array}{r}-0.044 \\
(0.089)\end{array}$ \\
\hline Organizational Growth & $\begin{array}{c}0.0015 \\
(0.0011)\end{array}$ & $\begin{array}{c}0.0017 \\
(0.0011)\end{array}$ & $\begin{array}{c}0.055^{*} \\
(0.025)\end{array}$ & $\begin{array}{c}0.067^{\star *} \\
(0.024)\end{array}$ & $\begin{array}{c}0.073^{*} \\
(0.035)\end{array}$ & $\begin{array}{c}0.058 \\
(0.034)\end{array}$ \\
\hline Organizational Age & $\begin{array}{l}0.243^{\star * *} \\
(0.079)\end{array}$ & $\begin{array}{l}0.214^{\star \star} \\
(0.083)\end{array}$ & $\begin{array}{r}-0.157^{*} \\
(0.074)\end{array}$ & $\begin{array}{r}-0.150 * \\
(0.076)\end{array}$ & $\begin{array}{r}-0.027 \\
(0.110)\end{array}$ & $\begin{array}{r}-0.194^{\dagger} \\
(0.106)\end{array}$ \\
\hline $\begin{array}{l}\text { Prior-Year Performance Relative } \\
\text { To Industry Average }\end{array}$ & $\begin{array}{l}-0.064^{* \star *} \\
(0.014)\end{array}$ & $\begin{array}{l}-0.062^{\star * *} \\
(0.013)\end{array}$ & $\begin{array}{r}-3.26 \\
(2.09)\end{array}$ & $\begin{array}{r}-2.81 \\
(2.04)\end{array}$ & $\begin{array}{c}3.42 \\
(4.33)\end{array}$ & $\begin{array}{r}-5.15^{\star} \\
(2.29)\end{array}$ \\
\hline $\begin{array}{l}\text { Prior-Year Domain Expansion } \\
\text { ( } \Delta \text { in Overall Scope of Operations) }\end{array}$ & $\begin{array}{c}0.010 \\
(0.007)\end{array}$ & $\begin{array}{c}0.008 \\
(0.007)\end{array}$ & $\begin{array}{c}0.296 \\
(0.617)\end{array}$ & $\begin{array}{c}0.639 \\
(0.633)\end{array}$ & $\begin{array}{r}-0.657 \\
(1.12)\end{array}$ & $\begin{array}{c}1.17 \\
(0.763)\end{array}$ \\
\hline Macroeconomic Factor & $\begin{array}{l}0.071^{\star *} \\
(0.023)\end{array}$ & $\begin{array}{l}0.110^{\star *} \\
(0.038)\end{array}$ & $\begin{array}{l}0.094^{\star *} \\
(0.035)\end{array}$ & $\begin{array}{c}0.015 \\
(0.048)\end{array}$ & $\begin{array}{c}0.004 \\
(0.067)\end{array}$ & $\begin{array}{c}0.042 \\
(0.070)\end{array}$ \\
\hline $\begin{array}{l}\text { Regulatory Punctuation Indicator } \\
\text { Variable }\end{array}$ & & $\begin{array}{r}-0.386 \\
(0.346)\end{array}$ & & $\begin{array}{r}-0.035 \\
(0.311)\end{array}$ & $\begin{array}{r}-0.391 \\
(0.476)\end{array}$ & $\begin{array}{c}0.232 \\
(0.422)\end{array}$ \\
\hline Time Since Regulatory Punctuation & & $\begin{array}{c}0.093^{*} \\
(0.044)\end{array}$ & & $\begin{array}{l}0.212^{* *} \\
(0.089)\end{array}$ & $\begin{array}{l}0.299^{\star *} \\
(0.133)\end{array}$ & $\begin{array}{c}0.138 \\
(0.122)\end{array}$ \\
\hline \# Succession Events & 247 & 247 & 192 & 192 & 94 & 98 \\
\hline$\chi^{2}$ & 65.4 & 72.0 & 40.2 & 51.7 & 12.9 & 73.8 \\
\hline Log-likelihood & -667.5 & -664.1 & -539.2 & -533.4 & -334.5 & -314.5 \\
\hline
\end{tabular}

Note. These models were estimated on 1,547 firm-year observations on hospitals and 1,301 firm-year observations on savings and loans. Standard errors are in parentheses below parameter estimates. ${ }^{\dagger}$ indicates $p<0.10,{ }^{*} p<0.05,{ }^{* *} p<0.01$, and ${ }^{* * *} p<0.001$, one-tailed $t$ tests for explanatory variables, two-tailed $t$ tests for control variables.

on the time clock is positive. This means that the regulatory punctuation was felt increasingly as time passed. In Model 6, which shows results for external succession, the estimates on both punctuation variables are nonsignificant. This means that the regulatory punctuation did not, as might be expected, increase the likelihood of outside succession, either immediately or over time.

\section{Performance}

Table 5 shows results on performance. We show two models for hospitals. The first is a baseline model; the second adds domain change, as measured by the one-year change in overall scope of operations. We show three models for thrifts. The first model is a baseline; the second and third models add two different measures of domain change: the one-year change in overall scope of operations and the one-year change in new lines of business, respectively.

Models 1 and 2 test Hypotheses 4 and 6 on hospitals. Hypothesis 4 predicts that post-punctuation domain expansion will initially harm hospitals, but that this negative effect will decline over time. If this were true, domain expansion following the regulatory punctuation would have a negative effect, and the interaction between postpunctuation domain expansion and the punctuation time clock would have a positive effect. Alas, there is no support for this hypothesis: The coefficient on postpunctuation domain change is nonsignificant, and the coefficient on the interaction with the regulatory punctuation time clock, while statistically significant, is unexpectedly negative.

Hypothesis 6 predicts an immediate performance boost 
HEATHER A. HAVEMAN, MICHAEL V. RUSSO, AND ALAN D. MEYER Organizational Environments in Flux

Table 5 The Effect of Regulatory Punctuation and Organizational Change on Performance

\begin{tabular}{|c|c|c|c|c|c|}
\hline \multirow[b]{2}{*}{ Model \# } & \multicolumn{2}{|c|}{ Hospitals } & \multicolumn{3}{|c|}{ Savings \& Loans } \\
\hline & 1 & 2 & 3 & 4 & 5 \\
\hline Constant & $\begin{array}{r}-0.161 \\
(0.614)\end{array}$ & $\begin{array}{r}-0.361 \\
(0.619)\end{array}$ & $\begin{array}{r}-0.003^{*} \\
(0.001)\end{array}$ & $\begin{array}{c}-0.004^{\star *} \\
(0.001)\end{array}$ & $\begin{array}{r}-0.003^{*} \\
(0.001)\end{array}$ \\
\hline Prior-Year Performance & $\begin{array}{l}0.729^{\star \star \star} \\
(0.027)\end{array}$ & $\begin{array}{l}0.733^{\star \star \star} \\
(0.027)\end{array}$ & $\begin{array}{l}0.629^{\star * *} \\
(0.026)\end{array}$ & $\begin{array}{l}0.608^{* * *} \\
(0.029)\end{array}$ & $\begin{array}{l}0.646^{\star \star \star} \\
(0.029)\end{array}$ \\
\hline Organizational Size & $\begin{array}{l}0.487^{\star * *} \\
(0.106)\end{array}$ & $\begin{array}{l}0.513^{* * *} \\
(0.108)\end{array}$ & $\begin{array}{c}-0.006^{\star *} \\
(0.002)\end{array}$ & $\begin{array}{c}-0.006^{\star \star \star} \\
(0.002)\end{array}$ & $\begin{array}{c}-0.005 \\
(0.004)\end{array}$ \\
\hline Organizational Growth & $\begin{array}{l}0.019^{\star * \star} \\
(0.002)\end{array}$ & $\begin{array}{l}0.019^{\star \star \star} \\
(0.002)\end{array}$ & $\begin{array}{c}0.0007 \\
(0.0004)\end{array}$ & $\begin{array}{c}0.0007 \\
(0.0004)\end{array}$ & $\begin{array}{l}0.002^{\star \star \star} \\
(0.0001)\end{array}$ \\
\hline Organizational Age & $\begin{array}{c}-0.335^{\star * *} \\
(0.082)\end{array}$ & $\begin{array}{c}-0.321^{\text {*** }} \\
(0.083)\end{array}$ & $\begin{array}{c}0.002^{\star * *} \\
(0.0003)\end{array}$ & $\begin{array}{l}0.002^{\star * *} \\
(0.0004)\end{array}$ & $\begin{array}{c}0.002^{* * *} \\
(0.0003)\end{array}$ \\
\hline Macroeconomic Factor & $\begin{array}{r}-0.085 \\
(0.057)\end{array}$ & $\begin{array}{r}-0.097^{\dagger} \\
(0.057)\end{array}$ & $\begin{array}{l}0.004^{\star * *} \\
(0.0002)\end{array}$ & $\begin{array}{l}0.004^{\star * *} \\
(0.0002)\end{array}$ & $\begin{array}{l}0.005^{\star \star \star} \\
(0.0002)\end{array}$ \\
\hline $\begin{array}{l}\text { Regulatory Punctuation Indicator } \\
\text { Variable }\end{array}$ & $\begin{array}{r}1.41^{\star \star} \\
(0.469)\end{array}$ & $\begin{array}{r}1.23^{\star \star} \\
(0.471)\end{array}$ & $\begin{array}{r}-0.003^{*} \\
(0.002)\end{array}$ & $\begin{array}{r}-0.004^{*} \\
(0.002)\end{array}$ & $\begin{array}{r}-0.002 \\
(0.002)\end{array}$ \\
\hline Time Since Regulatory Punctuation & $\begin{array}{l}-0.342^{\star * *} \\
(0.057)\end{array}$ & $\begin{array}{l}-0.277^{\star \star \star} \\
(0.061)\end{array}$ & $\begin{array}{c}0.0005 \\
(0.0004)\end{array}$ & $\begin{array}{c}0.0008 \\
(0.0006)\end{array}$ & $\begin{array}{r}-0.0009 \\
(0.0006)\end{array}$ \\
\hline Post-Punctuation Domain Expansion & & $\begin{array}{r}0.049^{\dagger} \\
(0.036)\end{array}$ & & $\begin{array}{l}0.056^{\star * \star} \\
(0.015)\end{array}$ & $\begin{array}{r}0.012^{\dagger} \\
(0.009)\end{array}$ \\
\hline $\begin{array}{l}\text { Post-Punctuation Domain Expansion } \\
\times \text { Time Since Punctuation }\end{array}$ & & $\begin{array}{c}-0.014^{\star \star} \\
(0.006)\end{array}$ & & $\begin{array}{r}-0.006 \\
(0.007)\end{array}$ & $\begin{array}{c}-0.00006 \\
(0.004)\end{array}$ \\
\hline Post-Punctuation CEO Succession & & $\begin{array}{l}1.60^{\star *} \\
(0.567)\end{array}$ & & $\begin{array}{c}0.001 \\
(0.002)\end{array}$ & $\begin{array}{l}0.013^{\star * *} \\
(0.002)\end{array}$ \\
\hline $\begin{array}{l}\text { Post-Punctuation CEO Succession } \\
\times \text { Time Since Punctuation }\end{array}$ & & $\begin{array}{l}-0.297^{\star \star} \\
(0.102)\end{array}$ & & $\begin{array}{c}-0.0004 \\
(0.001)\end{array}$ & $\begin{array}{l}-0.004^{\star * *} \\
(0.001)\end{array}$ \\
\hline Sample Selection Correction $(\lambda)$ & & & $\begin{array}{l}-0.038^{\star \star \star} \\
(0.005)\end{array}$ & $\begin{array}{l}-0.041^{* \star *} \\
(0.005)\end{array}$ & $\begin{array}{l}-0.043^{\star \star \star} \\
(0.006)\end{array}$ \\
\hline Log-likelihood & -3845.7 & -3837.5 & 2699.8 & 2707.5 & 2695.5 \\
\hline
\end{tabular}

Note. These models were estimated on 1,547 firm-year observations on hospitals and 1,301 firm-year observations on savings and loans. These models tested and corrected for first-order autocorrelation. Standard errors are in parentheses below parameter estimates. ${ }^{\dagger}$ indicates $p<0.10,{ }^{*} p<0.05,{ }^{\star *} p<0.01$, and ${ }^{* \star *} p<0.001$, one-tailed $t$ tests for explanatory variables, two-tailed $t$ tests for control variables. For each industry, the first model contains control variables only while the second adds domain change, measured as one-year change in overall scope of operations. For the thrift industry, the third model (Model 5 for the table) adds domain change, measured as activity in new lines of business.

from post-punctuation CEO succession, and a gradual attenuation of this benefit over time. It is supported by our analysis: The coefficient on post-punctuation CEO succession is positive, and the coefficient on the interaction with the regulatory punctuation time clock is negative. Hospitals that changed CEOs after the regulatory punctuation outperformed their counterparts, but this performance improvement was attenuated as time passed. The performance benefit of changing CEOs persisted for over five years $(1.60 / 0.297=5.4$ years to overturn the immediate effect of post-punctuation CEO succession).

Turning to the control variables, size and growth improved performance, perhaps because of economies of scale. The negative coefficient on age indicates that younger hospitals were better performers, perhaps because their newer facilities enhanced their efficiency, or because they were situated in more affluent regions (suburbs). The main effect of the regulatory punctuation was 
initially positive but later turned negative: There were positive and negative coefficients on the regulatory punctuation indicator and time clock, respectively. While regulatory change appears to have yielded direct short-term financial benefits, these were reversed about four years after the punctuation $(1.22 / 0.277=4.4$ years to extinguish the initial effect of the punctuation).

Models 4 and 5 test Hypotheses 5 and 6 on thrifts. Hypothesis 5 predicts that post-punctuation domain expansion will initially benefit thrifts, but that this positive effect will decline as time passes. If this were true, domain expansion following the regulatory punctuation would have a positive coefficient and the interaction between post-punctuation domain expansion and the punctuation time clock would have a negative coefficient. Hypothesis 5 is only partially confirmed: Increasing overall scope of operations in the post-punctuation environment improved performance more than expansion prior to the punctuation; however, this benefit did not diminish over time. Thus, thrifts that extended the scope of their domains after the regulatory punctuation captured lasting performance benefits. We also found partial support for Hypothesis 6, which concerns the effect of CEO succession, in our analysis of expanding activity in new lines of business. In Model 5, the coefficient on post-punctuation CEO succession is positive and statistically significant, while the coefficient on the interaction with the time clock is negative and significant. Based on Model 5, CEO succession soon after the regulatory punctuation gave thrifts a little over three years' advantage over their slowermoving competitors $(0.013 / 0.004=3.25$ years to exhaust the initial benefit of post-punctuation CEO succession).

Turning to the controls, our analysis indicates that older thrifts outperformed younger ones. Better financial performance was associated with prior CEO succession and with larger spreads between short- and long-term interest rates. Finally, the generally nonsignificant main effects of the two punctuation variables indicate that the effects of regulatory change on thrift performance were mediated by organizational actions.

\section{Discussion}

All industries are punctuated periodically by discontinuous change, and shifts in regulatory regimes often trigger these upheavals. We argued that regulatory punctuations drive changes in organizational domain, leadership, and performance. We also argued that the effects of punctuational change depend on industry context and require theory that is sensitive to time. Below, we summarize our findings and discuss the implications of our study for theory.
We developed a model of the consequences of punctuational environmental change for organizational change and performance, which was intended to complement current thinking about organizational change in stable environments (Amburgey et al. 1993; Barnett and Carroll 1995). Most research on organizations' adaptation to their environments adopts a gradualistic model of change, implicitly assuming that environments are stable or changing slowly, giving managers a chance to experiment with adaptive responses, while setting in motion processes that institutionalize successful experiments and weed out unsuccessful ones. Far less is known about whether or how organizations adapt to punctuational change in their environments. One contribution of our study lies in documenting the ability of major changes in government regulation to usher in sweeping changes in organizational environments. Our study complements and extends previous work on regulatory change (e.g., Miner et al. 1990, Singh et al. 1991, Barnett and Carroll 1993).

Table 6 summarizes our results. Hypotheses 1 and 4 pertained to regulatory punctuations that threaten organizations by increasing competition and reducing profit margins; these hypotheses were tested on hospitals. Our results support our predictions. Hospitals' initial response to the regulatory punctuation was to reduce their scope of services and focus on providing traditional acute care; only with the passage of time did hospitals broaden their services. We further expected that as the period of flux ended, hospitals that first retrenched and then expanded their domains would perform best. But our analyses did not substantiate this. Instead, domain changes by hospitals had minimal effects on post-punctuation performance.

Hypotheses 2 and 5 pertained to regulatory punctuations that present firms with new opportunities to expand their domains; these hypotheses were tested on savings and loans. As expected, the regulatory punctuation led thrifts to move rapidly into new lines of business. But evidence on the long-term performance implications of rapid domain expansion was mixed: Domain expansion any time after the regulatory punctuation improved performance; however, the benefits associated with domain expansion did not diminish as time passed.

Hypotheses 3 and 6 pertained to leadership succession in the wake of regulatory punctuations; these hypotheses were tested on both industries. Regulatory punctuations increased the likelihood of CEO succession across the board. This effect was not immediate; rather, hospitals and thrifts experienced gradual increases in succession rates. This observation is consistent with both a threatrigidity effect (Staw et al. 1981) and with the proposition that incumbent executives marshal resources to protect 
HEATHER A. HAVEMAN, MICHAEL V. RUSSO, AND ALAN D. MEYER Organizational Environments in Flux

Table 6 Summary of Hypotheses and Results

\begin{tabular}{|c|c|c|c|c|}
\hline $\begin{array}{l}\text { Hypothesis } \\
\text { (Industry) }\end{array}$ & $\begin{array}{l}\text { Antecedent } \\
\text { Factor }\end{array}$ & $\begin{array}{l}\text { Predicted } \\
\text { Outcome }\end{array}$ & $\begin{array}{l}\text { Results for } \\
\text { Hospitals }\end{array}$ & $\begin{array}{l}\text { Results for } \\
\text { Thrifts }\end{array}$ \\
\hline $\begin{array}{l}1 \\
\text { Hospitals } \\
\text { Only }\end{array}$ & $\begin{array}{l}\text { Regulatory punctuation that } \\
\text { reduces entry barriers or } \\
\text { price margins. }\end{array}$ & $\begin{array}{l}\text { Organizations will contract } \\
\text { their domains in the short run, } \\
\text { but will subsequently expand. }\end{array}$ & $\begin{array}{l}\text { Strong support (overall } \\
\text { scope of activities) }\end{array}$ & \\
\hline $\begin{array}{l}2 \\
\text { Thrifts } \\
\text { Only }\end{array}$ & $\begin{array}{l}\text { Regulatory punctuation that } \\
\text { expands the allowed scope of } \\
\text { activities }\end{array}$ & $\begin{array}{l}\text { Organizations will expand } \\
\text { their domains immediately, } \\
\text { but the rate of expansion will } \\
\text { slow as time passes. }\end{array}$ & & $\begin{array}{l}\text { Partial support (overall } \\
\text { scope of activities) } \\
\text { Strong support (expansion } \\
\text { into new lines of business) }\end{array}$ \\
\hline $\begin{array}{l}3 \\
\text { Hospitals } \\
\text { \& Thrifts }\end{array}$ & Any regulatory punctuation. & $\begin{array}{l}\text { Rates of CEO succession will } \\
\text { rise slowly over time. }\end{array}$ & Strong support & Strong support \\
\hline $\begin{array}{l}4 \\
\text { Hospitals } \\
\text { Only }\end{array}$ & $\begin{array}{l}\text { Regulatory punctuation that } \\
\text { reduces entry barriers or } \\
\text { price margins. }\end{array}$ & $\begin{array}{l}\text { Domain expansion will harm } \\
\text { performance, but this } \\
\text { negative effect will diminish } \\
\text { as time passes. }\end{array}$ & No support & \\
\hline $\begin{array}{l}5 \\
\text { Thrifts } \\
\text { Only }\end{array}$ & $\begin{array}{l}\text { Regulatory punctuation that } \\
\text { expands the allowed scope of } \\
\text { activities. }\end{array}$ & $\begin{array}{l}\text { Domain change will improve } \\
\text { performance, but this positive } \\
\text { effect will diminish as time } \\
\text { passes. }\end{array}$ & & $\begin{array}{l}\text { Partial support } \\
\text { (performance improvement } \\
\text { does not diminish over time) }\end{array}$ \\
\hline $\begin{array}{l}6 \\
\text { Hospitals } \\
\text { \& Thrifts }\end{array}$ & Any regulatory punctuation. & $\begin{array}{l}\text { CEO succession will improve } \\
\text { performance, but this positive } \\
\text { effect will diminish as time } \\
\text { passes }\end{array}$ & Strong support & Partial support \\
\hline
\end{tabular}

their positions (Pfeffer 1982, pp. 289-332). However, those hospitals and thrifts that did move swiftly to change leaders after the punctuation outperformed those whose incumbent CEOs held on to their jobs. This effect was stronger in the hospital industry than in the thrift industry, perhaps because the regulatory punctuation in the hospital industry was unambiguously threatening, while the regulatory punctuation in the thrift industry was both beneficent (it created opportunities for expansion) and threatening (it led to increased competition with other financial-services firms-notably commercial banks). In sum, our results are consistent with the idea that punctuational change opens a window of opportunity for leadership change, and that firms that seize this opportunity outperform those that do not.

Our analysis extends prior work on regulatory punctuations and organizational change and broadens this stream of research in several ways. First, like Singh et al.'s (1991) analysis of voluntary social-service organizations in Toronto, we showed that the content of regulatory change carries important explanatory value. Changes that threatened firms elicited different reactions than changes presenting new opportunities. Second, we used a fine-grained measure of performance (short-term financial performance) rather than the coarse-grained measure (survival) used in previous studies (e.g., Miner et al. 1990, Singh et al. 1991).

Third and most important, we found that firms responding to punctuations by changing CEOs improved their subsequent performance. In this regard, our results provide an interesting contrast to those reported by Miner et al. (1990). These authors studied how a population of Finnish newspapers responded to external shocks, including several regulatory shocks - the onset of foreign-news censorship, apriori censorship, and oppressive Russian oversight. All but foreign-news censorship triggered organizational transformations (changing content, language, editor, etc.); however, such transformations consistently increased the chance of newspaper failure. Our analysis goes beyond Miner et al. (1990) by directly comparing transitions after regulatory punctuations with transitions during times of tranquility. Our findings suggest that regulatory punctuations loosen the grip of organizational inertia and shift the costs and benefits associated 
with organizational change. By introducing time-related measures of regulatory punctuations, we were able to tease apart effects that may have been confounded in prior research. Thus, our study offers a more complete picture of the impacts of regulatory punctuations on organizational dynamics.

Fine-tuning theories about intertemporal effects of regulatory change should lead to important discoveries. For example, it may well be the case that symbolic actions occur immediately after punctuations, but that substantive actions take time to formulate and execute. To further speculate, considerable time may be have to pass before institutional actors and incumbents create a "collective construction of compliance" (Aldrich 1999, p. 208) to new regulations. Another possibility is that intended consequences occur immediately after regulatory punctuations, while unintended consequences suffuse through the industry only gradually. Barnett and Carroll (1993) and Wade et al. (1998) found that unintended consequences follow regulatory change, but only after considerable lengths of time.

\section{Conclusion}

Time and History. History and temporal dynamics play central roles in our conception of how environmental punctuations rearrange industries. Organizational research has traditionally focused on the enduring and stable features of organizations and the environments they inhabit; until recently, far less attention has been paid to history, flux, dynamics, and transformation (Clark 1985, Ancona and Chong 1996). Even longitudinal studies of organizations are typically ahistorical in that theorized relationships are assumed to be time-invariant; timeseries analyses usually treat history as the continual unfolding of stable causal processes (Isaac and Griffin 1989). As a consequence, previous research has generally ignored the possibility that profound changes in organizational structures, activities, and performance occur suddenly and may be caused by environmental shifts affecting all organizations of a particular type simultaneously. In contrast, we believe that environmental punctuations partition the history of an industry into periods during which different causal processes operate.

Adaptation Requires Good Timing. The timing of action plays a central role in our understanding of how organizations adjust to regulatory punctuations. When regulatory punctuations rattle industry structures and redraw industry boundaries, periods of environmental disequilibrium ensue, opening windows of opportunity for organizational change. These windows of opportunity may not remain open long, however. The effectiveness of organizational actions often depends on whether organizations can time small interventions so that the unfolding of endogenous processes amplifies their consequences (March 1981, p. 575). Our analyses of the hospital industry suggest that one type of internal change-CEO successionbenefitted these organizations most during periods of flux in their institutional environment.

The Need for a Punctuated-Equilibrium Model of Organizational Change. Historically, organizational theory has addressed stability and incremental change far more extensively than process and radical change. But gradualism is an assumption of social theory, not a fact of social life. Gradualistic assumptions conflict with observations of revolutionary change that sweeps across entire industries. It is not our aim to discredit gradualism and replace it with a punctuational model of organizational evolution. We view change as occurring in both continuous and discontinuous modes. But we believe that adopting a punctuational perspective will enable us to map episodes of organizational upheaval more accurately than the gradualist perspective that has generally dominated the debate about organizational change.

Our analysis of the impact of regulatory punctuations has offered some clues about how organizations behave when they are far from equilibrium. But this is just a first step. A great more must be learned about how technological breakthroughs, market crashes, political upheavals, and other environmental punctuations affect both established organizations and new entrepreneurial ventures.

\section{Acknowledgments}

The authors gratefully acknowledge the support of the U.S. Army Research Institute for the Behavioral and Social Sciences and the help of James Goes in collecting and analyzing the hospital data. The authors thank seminar participants at the Universities of British Columbia, Oregon, Washington, and Illinois and two anonymous Organization Science reviewers for their helpful comments. Finally, the authors thank Anne Miner for her keen editorial eye.

\section{Endnotes}

${ }^{1}$ It would be preferable to estimate a system of structural equations, and thereby incorporate these circular relationships explicitly. Unfortunately, estimation of a system of equations where one of the outcomes is a discrete variable (here, CEO succession) is not yet technically feasible (SAS technical support personnel, personal communication, March 22, 1999). Accordingly, we estimate separate models for the three outcomes and handle bidirectional causation with control variables.

${ }^{2}$ For hospitals, data on nontraditional service areas were not available until after the regulatory punctuation.

${ }^{3}$ We recognize that the effects of external succession are likely to be stronger than the effects of internal succession. Unfortunately, for hospitals, we could not ascertain whether or not the CEO was appointed 
from outside the organization. Thus, we analyzed inside vs. outside succession events for thrifts only.

\section{References}

Aldrich, H. E. 1999. Organizations Evolving. Sage, Thousand Oaks, CA.

Amburgey, T. L., D. Kelly, W. P. Barnett. 1993. Resetting the clock: The dynamics of organizational change and failure. Admin. Sci. Quart. 38 51-73.

Ancona, D., C. L. Chong. 1996. Entrainment: Pace, cycle, and rhythm in organizational behavior. Barry M. Staw and Larry L. Cummings, eds. Research in Organizational Behavior 18 251-284.

Anderson, P. M., L. Tushman. 1990. Technological discontinuities and dominant designs: A cyclical model of technological change. Admin. Sci. Quart. 35 604-633.

Astley, W. G. 1985. The two ecologies: Population and community perspectives on organizational evolution. Admin. Sci. Quart. 30 224-241.

Barnett, W. P., G. R. Carroll. 1993. How institutional constraints affected the organization of early U.S. telephony. J. Law, Econom. Organ. 9 98-126.

- -1995 . Modelling internal organizational change. Ann. Rev. Soc. 21 217-236.

Baum, J. A. C., H. J. Korn, S. Kotha. 1995. Dominant designs and population dynamics in telecommunications services: Founding and failure of facsimile transmission service organizations, 19651992. Soc. Sci. Res. 24 97-135.

Belsley, D. A., E. Kuh, R. E. Welsch. 1980. Regression Diagnostics. John Wiley and Sons, New York.

Bernstein, M. H. 1955. Regulating Business by Independent Commission. Princeton University Press, Princeton, NJ.

Blau, P. M. 1977. Inequality and Heterogeneity: A Primitive Theory of Social Structure. Free Press, New York.

Boeker, W. P. 1992. Power and managerial dismissal: Scapegoating at the top. Admin. Sci. Quart. 37 400-421.

- 1997. Executive migration and strategic change: The effect of top manager movement on product-market entry. Admin. Sci. Quart. 42 213-236.

Bollerslev, T. 1986. Generalized autoregressive conditional heteroskedasticity. J. Econometrics 31 307-327.

Carroll, G. R. 1987. Publish or Perish: The Organizational Ecology of Newspaper Industries. JAI Press, Greenwich, CT.

Carron, A. S. 1983. The Rescue of the Thrift Industry. The Brookings Institution, Washington, D.C.

Clark, P. 1985. A review of the theories of time and structure for organizational sociology. S. Bacharach and S. Mitchell, eds. Research in the Sociology of Organizations 4 35-709. JAI Press, Greenwich, CT.

Cole, D. W. 1971. Measuring savings and loan profitability. Federal Home Loan Bank J. October 1-7.

Cyert, Richard M., and James G. March. 1963. A Behavioral Theory of The Firm. Prentice-Hall, Englewood Cliffs, NJ.

DiMaggio, P. J., W. W. Powell. 1983. The iron cage revisited: Institutional isomorphism and collective rationality in organizational fields. Amer. Soc. Rev. 48 147-160.

Dobbin, F. R., T. Dowd. 2000. The market that anti-trust built: Public policy, private coercion, and railroad acquisitions, 1825-1922. Amer. Soc. Rev. 65 635-637.

_ J. R. Sutton. 1993. The strength of a weak state: The employment rights revolution and the rise of human resources management divisions. Amer. J. Soc. 104 441-476.

- — J J. W. Meyer, W. R. Scott. 1993. Equal opportunity law and the construction of internal labor markets. Amer. J. Soc. 99 396-427.

Edelman, L. B. 1990. Legal environments and organizational governance: The expansion of due process in the American workplace. Amer. J. Soc. 95 1401-1440.

—. 1992. Legal ambiguity and symbolic structures; Organizational mediation of civil rights law. Amer. J. Soc. 97 1531-1576.

Eisenhardt, K. M. 1989. Making fast strategic decisions in high-velocity environments. Acad. Management J. 32 543-576.

Eldredge, N., S. J. Gould. 1972. Punctuated equilibria: An alternative to phyletic gradualism. T. Schopf, ed. Models in Paleobiology San Francisco, Freeman, Cooper, 82-115.

Fligstein, N. 1990. The Transformation of Corporate Control. Harvard University Press, Cambridge, MA.

Gamson, W. A., N. A. Scotch. 1964. Scapegoating in baseball. Amer. J. Soc. 70 69-72.

Gallant, A. R., J. J. Goebel. 1976. Nonlinear regression with autoregressive errors. J. Amer. Statist. Assoc. 71 961-967.

Gersick, C. J. G. 1991. Revolutionary change theories: A multilevel exploration of the punctuated equilibrium paradigm. Acad. Management Rev. 1 10-36.

Goes, J. B. 1989. Strategic change and organizational performance: A longitudinal study of California hospitals. Unpublished Ph.D. dissertation, University of Oregon, Eugene, OR.

— S. H. Park. 1997. Interorganizational links and innovation: the case of hospital services. Acad. Management J. 40 673-696.

Gould, S. Jay, N. Eldredge. 1977. Punctuated equilibria: The tempo and mode of evolution reconsidered. Paleobiology 3 115-151.

Granovetter, M. S. 1985. Economic action and social structure: The problem of embeddedness. Amer. J. Soc. 91 481-510.

Grusky, O. 1963. Managerial succession and organizational effectivess. Amer. J. Soc. 69 21-31.

Guest, R. H. 1962. Managerial succession in complex organizations. Amer. J. Soc. 68 47-56.

Guthrie, D. L. M. Roth. 1999. The state, courts, and maternity leave policies in U.S. organizations: Specifying institutional mechanisms. Amer. Soc. Rev. 64 41-63.

Hannan, M. T., J. Freeman. 1984. Structural inertia and organizational change. Amer. Soc. Rev. 49 149-164.

—, 1989. Organizational Ecology. Harvard University Press, Cambridge, MA.

Harrison, J. R., D. L. Torres, S. Kukalis. 1988. The changing of the guard: Turnover and structural change in top-management positions. Admin. Sci. Quart. 33 211-232.

Haveman, H. A. 1992. Between a rock and a hard place: Organizational change and performance under conditions of fundamental environmental transformation. Admin. Sci. Quart. 37 48-75.

Hawley, A. H. 1950. Human Ecology: A Theory of Community Structure. Ronald Press, New York.

Heckman, J. J. 1979. Sample selection bias as a specification error. Econometrica 47 153-161. 
Isaac, L. W., and L. J. Griffin. 1989. Ahistoricism in time-series analysis of historical process: Critique, redirection, and illustrations from U.S. labor history. Amer. Soc. Rev. 54 873-890.

Jepperson, R. L. 1991. Institutions, institutional effects, and institutionalization. Walter W. Powell, Paul J. DiMaggio, eds. The New Institutionalism in Organizational Analysis, University of Chicago Press, Chicago, IL. 143-163.

Joskow, P. L. 1988. The evolution of competition in the electric power industry. Ann. Rev. Energy 13 215-238.

Keck, S. L., M. L. Tushman. 1993. Environmental and organizational context and executive team structure. Acad. Management J. 36 1314-1344.

Kelly, E., F. Dobbin. 1999. Civil rights law at work: Sex discrimination and the rise of maternity leave policies. Amer. J. Soc. 105 455492.

Koza, M. P. 1988. Regulation and organization: Environmental niche structure and administrative organization. S. Bacharach, ed. Research in the Sociology of Organizations 6 JAI Press, Greenwich, CT. 183-201.

Leone, R. A. 1985. Who Profits? Winners, Losers, and Government Regulation. Basic Books, New York.

Levinthal, D., J. G. March. 1993. The myopia of learning. Strategic Management J. 14 95-112.

MacAvoy, P. W., K. Robinson. 1983. Winning by losing: The AT\&T settlement and its impact on telecommunications. Yale J. Regulation 1 1-42.

— -1985 . Losing by judicial policymaking: The first year of the AT\&T divestiture. Yale J. Regulation $2225-262$.

March, James G. 1981. Footnotes to organizational change. Admin. Sci. Quart. 26 563-577.

McLean, K. A. 1980. Legislative background of the Depository Institutions and Monetary Control Act of 1980. Savings and Loan Asset Management Under Deregulation. Proc. 6th Ann. Conf. Federal Home Loan Bank of San Francisco. December 1980. 1739.

Melnick, G. A., J. Zwanziger. 1988. Hospital behavior under competition and cost-containment policies. J. Amer. Medical Assoc. 260 2669-2675.

Merton, R. K. 1936. The unanticipated consequences of purposive social action. Amer. Soc. Rev. 1 894-904.

Meyer, A. D. 1982. Adapting to environmental jolts. Admin. Sci. Quart. 27 515-537.

— , G. R. Brooks, J. B. Goes. 1993. Environmental jolts and industry evolution: Orgnizational responses to discontinuous change. Strategic Management J. 11 93-110.

Meyer, J. W., B. Rowan. 1977. Institutionalized organizations: Formal structure as myth and ceremony. Amer. J. Soc. 83 340-363.

Mezias, S. J. 1990. An institutional model of organizational practice: Financial reporting at the Fortune 200. Admin. Sci. Quart. 35 431457.

Miner, A. S., T. L. Amburgey, T. M. Stearns. 1990. Interorganizational linkages and population dynamics: Buffering and transformational shields. Admin. Sci. Quart. 35 689-713.

— , P. R. Haunschild. 1996. Population-level learning. Larry L. Cummings and Barry M. Staw, eds. Research in Organizational Behavior JAI Press, Greenwich, CT 17 115-167.

Pfeffer, J. 1981. Management as symbolic action: The creation and maintenance of organizational paradigms. Barry M. Staw and Larry L. Cummings, eds. Research in Organizational Behavior JAI Press, Greenwich, CT. 3 1-52.

- 1982. Power in Organizations. Ballinger, Cambridge, MA.

—, G. R. Salancik. 1978. The External Control of Organizations. Harper and Row, New York.

Romanelli, E. 1989. Organizational birth and population variety: A community perspective on origins. L. Cummings and B. Staw, eds. Research in Organizational Behavior JAI Press, Greenwich, CT. 11 211-246.

Roy, W. G. 1997. Socializing Capital: The Rise of the Large Industrial Corporation in America. Prnceton University Press, Princeton, NJ.

Russo, M. V. 2001. Institutions and early population dynamics: Independent power production in America, 1978-1992. Admin. Sci. Quart. 46 57-86.

SAS Institute. 1993. SAS/ETS Manual. SAS Institute Inc., Cary, NC.

Scott, W. R. 1998. Organizations: Rational, Natural, and Open Systems, 4th ed. Prentice-Hall, Saddle River, NJ.

Selznick, P. 1949. TVA and the Grassroots. University of California Press, Berkeley, CA.

Shepherd, W. G. 1985. Public Policies Toward Business. Irwin, Homewood, IL.

Sine, W. D., H. A. Haveman, P. S. Tolbert. 2001. The institutional context of founding variation in the emerging independent power industry. Working paper, University of Maryland, College Park, MD.

Singh, J. V., R. J. House, D. J. Tucker. 1986. Organizational change and organizational mortality. Admin. Sci. Quart. 31 587-611.

— D. J. Tucker, A. G. Meinhard. 1991. Institutional change and ecological dynamics. Walter W. Powell and Paul J. DiMaggio, eds. The New Institutionalism in Orgnizational Analysis. University of Chicago, Chicago, IL. 390-422.

Starbuck, W. H., A. Greve, B. L. T. Hedberg. 1978. Responding to crisis. J. Bus. Admin. 9 111-137.

Staw, B. M., L. E. Sandelands, J. E. Dutton. 1981. Threat-rigidity effects in organizational behavior: A multilevel analysis. Admin. Sci. Quart. 26 501-524.

Stearns, L. Brewster, K. Allan. 1996. Economic behavior in institutional environments: The corporate merger wave of the 1980s. Amer. Soc. Rev. 61 699-718.

Sutton, J. R., R. Dobbin, J. W. Meyer, W. R. Scott. 1994. The legalization of the workplace. Amer. J. Soc. 99 944-971.

Thompson, J. D. 1967. Organizations in Action. McGraw-Hill, New York.

Tuma, N. B. 1976. Rewards, resources, and the rate of mobility: A nonstationary multivariate stochastic model. Amer. Soc. Rev. 41 338-360.

- 1993. Invoking RATE. DMA Corporation, Palo Alto, CA.

Tushman, M. L., P. Anderson. 1986. Technological discontinuities and organizational environments. Admin. Sci. Quart. 31 439-465.

_ phosis model of convergence and reorientation. Larry L. Cummings and Barry M. Staw, eds. Research in Organizational Behavior. JAI Press, Greenwich, CT. 7 171-222.

Tyre, M. J., W. J. Orlikowski. 1994. Windows of opportunity: Temporal patterns of technological adaptation in organizations. Organ. Sci. 5 98-118. 
U.S. General Accounting Office. 1991. Thrifts and Housing Finance: Implications of a Stricter Qualified Thrift Lender Test. U.S. General Accounting Office, Washington, DC.

Vietor, H. K. 1989. Strategic Management in the Regulatory Environment: Cases and Industry Notes. Prentice Hall, Englewood Cliffs, NJ.

Virany, B. M., L. Tushman, E. Romanelli. 1992. Executive succession and organization outcomes in turbulent environments: An organization learning approach. Organ. Sci. 3 72-91.

Wade, J. B., A. Swaminathan, M. Scott Saxon. 1998. Normative and

Accepted by Anne Miner. resource flow consequences of local regulations in the American brewing industry, 1845-1918. Admin. Sci. Quart. 43 905-935.

Wholey, D. R., S. M. Sanchez. 1991. The effects of regulatory tools on organizational populations. Acad. Management Rev. $16743-$ 767.

Zammuto, R. F. 1988. Organizational adaptation: Some implications of organizational ecology for strategic choice. J. Management Stud. 25 105-120.

Zucker, L. G. 1977. The role of institutionalization in cultural persistence. Amer. Soc. Rev. 42 726-743. 